\title{
Greece: Unstable Landscapes and Underwater Archaeology
}

\author{
Nena Galanidou, Katerina Dellaporta, \\ and Dimitris Sakellariou
}

\begin{abstract}
The submerged archaeology of Greece extends from the Palaeolithic to the early Byzantine period. It offers valuable information on some of the critical themes of Eurasian prehistory: hominin dispersals, settlement patterns, strategies of survival, population movements and sea voyaging, communication and trade, highenergy destructive events and climate change. This overview focuses on the prehistoric record. It includes partly or fully submerged palaeontological sites as well as archaeological sites. All these are testimonies to the more extensive coastal mosaic of biotopes that were available to prehistoric people prior to c. 4000 cal BP in the Holocene and during the cold and arid periods of the Pleistocene. They show coastal and maritime lifeways in dynamically changing landscapes connecting Asia and Europe. They are now located on the Greek continental shelf due to eustatic and isostatic
\end{abstract}

N. Galanidou $(\bowtie)$

Department of History and Archaeology,

University of Crete, Rethymno, Greece

e-mail: galanidou@uoc.gr

K. Dellaporta

Hellenic Ministry of Culture and Sports,

Byzantine and Christian Museum, Athens, Greece

D. Sakellariou

Hellenic Centre for Marine Research, Institute of Oceanography, Anavyssos, Greece

e-mail: sakell@hcmr.gr change as well as the heavy imprint of tectonic activity.

\section{Keywords}

Submerged landscapes - Underwater - Caves · Neolithic $\cdot$ Middle Palaeolithic $\cdot$ Early Bronze Age $\cdot$ Tectonics $\cdot$ Kalamakia Cave $\cdot$ Agios Petros $\cdot$ Pavlopetri

\subsection{Introduction}

Greece is a country of strong maritime traditions with deep historical roots and evidence of earliest human occupation extending back to the Lower Palaeolithic at least 0.5 million years ago (Galanidou et al. 2016a, b). The modern territory of the Greek State includes a large portion of the Aegean Basin to the east and the Ionian Basin to the west, with a total of 3500 offshore islands that represent the high points of a drowned coastal shelf, and $17,000 \mathrm{~km}$ of coastline, a quarter of the total Mediterranean coastline. The greater part of this figure is represented by islands (Fig. 19.1). Greece is also a region of extreme, long-term tectonic activity. Because of its position at the convergence of the tectonic plates of Africa, Europe and Anatolia, intense earthquake activity and volcanism are present, resulting in uplift or subsidence of the land surface at both localized and regional scales. These have amplified or 


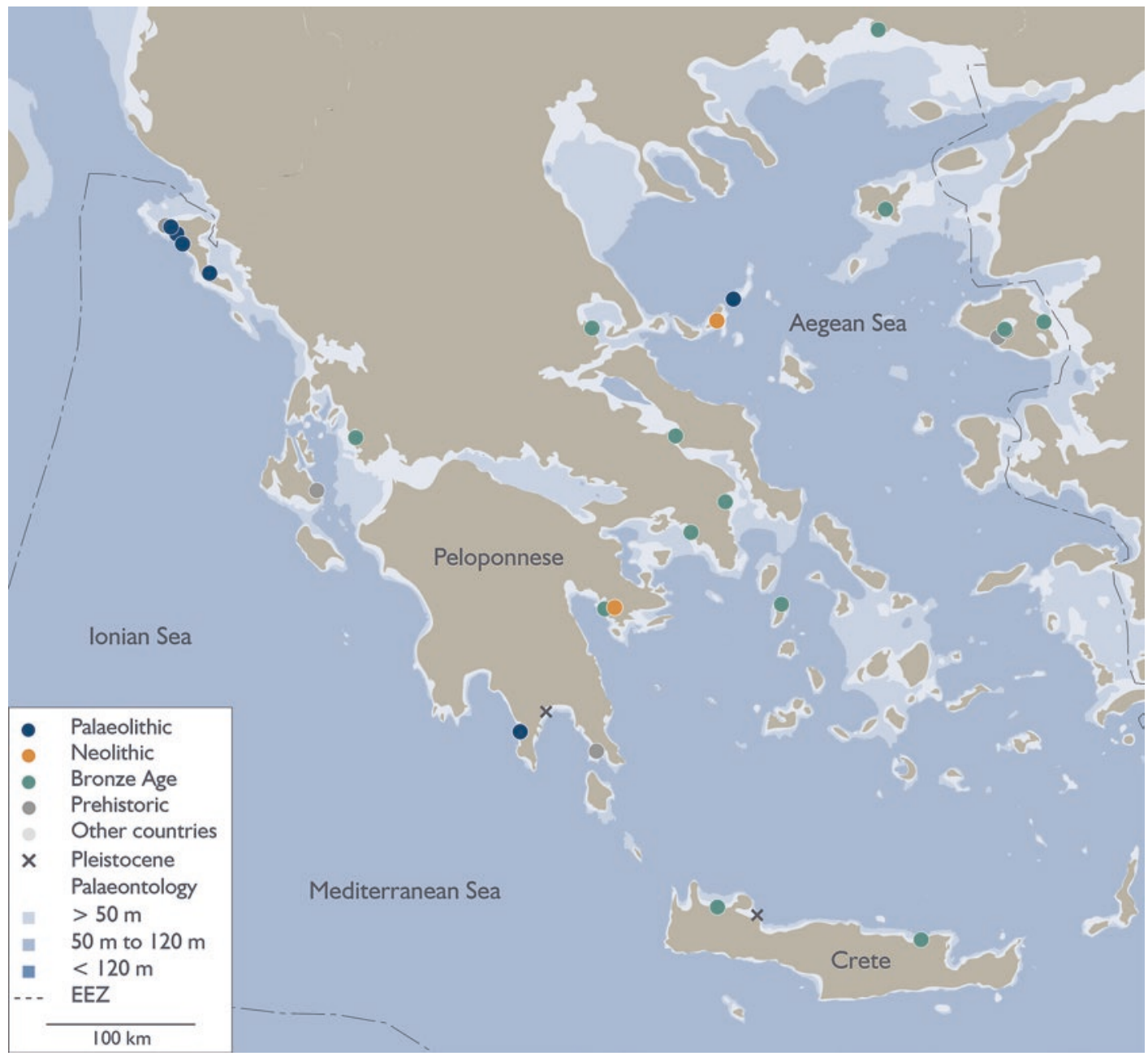

Fig. 19.1 Map of Greece, showing the submerged prehistoric sites. Site information from the SPLASHCOS Viewer http://splashcos-viewer.eu. Drawing by Moritz Mennenga

moderated the effects of eustatic sea-level change associated with the growth and melting of the continental ice sheets, with important consequences for palaeogeographic reconstructions and the position of prehistoric coastlines (Flemming 1968a, b; Lambeck 1995, 1996; Perissoratis and Conispoliatis 2003; Sakellariou and Galanidou 2016, 2017; Sakellariou et al. 2017).

The archaeological record on the coast and underwater includes three distinct categories (excluding shipwrecks):
1. Settlements, structures or karstic features that were in the past on dry land but are now fully inundated

2. Settlements and caves on the present-day coastline that partly extend into shallow waters or are bounded or eroded by the sea

3. Structures for the exploitation of marine resources or maritime activity such as saltpans, fish farms, harbour installations, lighting/signalling constructions and quarries for the extraction of coastal rocks 
The first two categories are the subject of this study. Here we gather information from a literature review, personal communication with the pioneers of underwater and coastal research, namely, Augustus Sordinas and Nic Flemming, as well as our own hands-on experience, to put together an overview of the prehistoric sites and landscapes of the Greek continental shelf up to and including the Early Bronze Age.

The submerged prehistoric sites from Greece recorded in the SPLASHCOS database number 27 entries (Fig. 19.1). These sites are testimony to an extensive mosaic of coastal biotopes that were available prior to about $4000 \mathrm{cal} \mathrm{BP}$. The seabed has yielded partially or totally inundated settlements with architectural features (remains of walls, foundations or stone-built structures), loose finds such as stone tools and ceramics, hoards and cave sites containing bones of extinct Pleistocene animals. Although of pure palaeontological interest, the latter sites are important in showing that terrestrial cave deposits can be preserved during sea-level rise and are not completely washed out and destroyed, and we include them in the present discussion. We also pursue in a systematic way cave sites on the modern coastline that are partially submerged or inaccessible today except from the shoreline or the sea, but with stratified terrestrial deposits containing artefacts, faunal remains and palaeoenvironmental indicators in their dry interiors. However, we exclude the submerged sites dating from the Middle Bronze Age onwards that today lie in the shallow waters of Greece due to coastal subsidence. We organise the material in chronological order, beginning with palaeontological remains and cave sites and proceeding to coastal villages and other finds. As the volume of information is large, the present account aims to highlight the main patterns in the submerged record rather than offer an exhaustive appraisal of individual sites (for full details see http://splashcos-viewer.eu). To capture the current dynamism of continental shelf prehistoric research, we also present recent work on seabed surveying and mapping motivated by explicit archaeological and historical questions.

\subsection{Archaeological Context}

The extensive submerged landscapes of the Greek territory hold clues to understanding some of the foundational developments of early European history. These include the earliest Pleistocene hominin expansions out of Africa and Asia following terrestrial routes into Europe, the deep history of Palaeolithic sea voyaging, Neolithic farmer diasporas from Anatolia and the Near East, some of which certainly followed coastal pathways and involved sea crossings and island colonisation, and the seaborne trade of the Bronze Age that underpinned Europe's earliest urban civilization, the so-called Minoan, reaching far-flung locations across the eastern Mediterranean Sea.

The Aegean is emerging as a probable basin where land connections opened up between Anatolia and the Balkan Peninsula when sea level was lower than the present, offering extensive and productive, but now submerged, landscapes and routes of dispersal from Early Pleistocene times onwards for animal and hominin populations. The presence of Middle Pleistocene archaeological finds on the island of Lesbos, and Early Pleistocene palaeontological finds there and on other islands in the east Aegean, is indirect evidence of sea-level fluctuations in the early Quaternary, since these islands were likely only accessible via land bridges or short sea crossings made possible during low sea-level stands (Galanidou et al. 2013, 2016a, b). On the island of Lesbos, there are seven Early Pleistocene fossiliferous sites with continental faunas that demonstrate biogeographic integration with Asia (Lyras and van der Geer 2007). Both the PlioPleistocene palaeontological record of Greece (e.g. Koufos and Kostopoulos 2016) and the Lower Palaeolithic archaeology of the eastern Aegean Sea (Galanidou et al. 2013, 2016a, b) prompt the articulation of a new scenario for the early penetration and later colonization of Europe via terrestrial pathways now inundated on the Aegean seafloor. Research in marine geoscience and Palaeolithic archaeology is intensifying in the field and the laboratory to map these sub- 
merged Aegean landscapes, to identify the most promising areas for underwater archaeological survey and to reconstruct the transformation of landscapes and seascapes during the low sealevel periods of the Pleistocene. The ultimate aim is to obtain a holistic view of northeast Mediterranean palaeogeography-what was land, coast and sea-and assess its impact on the history of hominin dispersals.

The Aegean and Ionian regions are also emerging as a likely focus for initial attempts at sea crossings and early sea voyaging as documented by the colonisation or exploitation of offshore islands, extending back well before the spread of farming to at least 13,000 years ago and possibly earlier (Perlès 1979; Renfrew and Aspinall 1990; Kopaka and Matzanas 2009; Strasser et al. 2010; Ammerman 2014). The site of Maroulas on the island of Kythnos (in the Cyclades) and stratum $\mathrm{X}$ at Knossos on Crete offer unequivocal evidence for maritime travels at around 9500 and 9000 years ago, respectively (Evans 1994; Efstratiou 2005; Sampson et al. 2010; Galanidou 2011). Since the earliest points of arrival or departure, and the most favourable terrain for the establishment of settlements, are likely to have been located on or close to the seashore, especially on the smaller islands, much if not most of the relevant evidence for early sea voyaging must now lie underwater.

All the above factors point to the likely significance of the Greek shelf as a key area for investigating Eurasian prehistory.

\subsection{Geological and Palaeogeographical Background}

Geological processes play an unusually significant role in determining the effects of eustatic changes in sea-level fluctuation on the position of prehistoric coastlines, and the area of land made available during low sea-level stands. This is especially the case in the Aegean Basin, where the crust 'flows' to the south-south-west, confined between the North Anatolian and Kephallinia Faults to the north and north-west and the East Hellenic Trench to the south-east, and overrides the subducting oceanic crust of the Eastern Mediterranean. The deformation is accommodated by dextral and sinistral shearing which creates a complex pattern of localized subsidence along with local uplift (Sakellariou and Tsampouraki-Kraounaki 2018).

The island of Crete is a good example of the complexities associated with local tectonic deformation. The island as a whole is undergoing general long-term uplift but is divided by multi-directional faulting into several different blocks displaying different rates of vertical movement (Pirazzoli et al. 1982; Pirazzoli 1988; Pirazzoli et al. 1996; Stiros 2001; Van Hinsbergen and Meleunkamp 2006; Shaw et al. 2008; Mouslopoulou et al. 2015). The highest uplift rate is in western Crete, which has risen dramatically in historical times, with evidence of uplift by about $7 \mathrm{~m}$ in AD 365 as a result of a single powerful earthquake (Shaw et al. 2008), holding out the prospect of discovering early prehistoric coastal evidence that may have been lifted clear of late glacial sea-level rise. These same processes also result in localised subsidence, which is why some Bronze Age sites on Crete are submerged below present sea level.

However, the long-term trend in the Aegean Basin as a whole is subsidence (Lykousis 2009), and this has two important archaeological consequences. First, on the Pleistocene time scale, it means that progressively more extensive areas of land would have been exposed for human exploitation during periods of low sea level as one goes further back in time. According to the reconstructions of Lykousis (2009), during the glacial maxima of MIS (Marine Isotope Stage) 10 and 12, at $\sim 340 \mathrm{ka}$ and $420 \mathrm{ka}$, respectively, the Aegean Basin would have been an almost continuous land mass connecting Anatolia and the Greek mainland, with some large inland lake basins (Fig. 19.2). Crete would have remained an offshore island but separated by only a very narrow strait at its western end from the Greek mainland (Sakellariou and Galanidou 2016, 2017). These episodes were well within the period when early humans were present in the region and have significant implications for patterns of population 


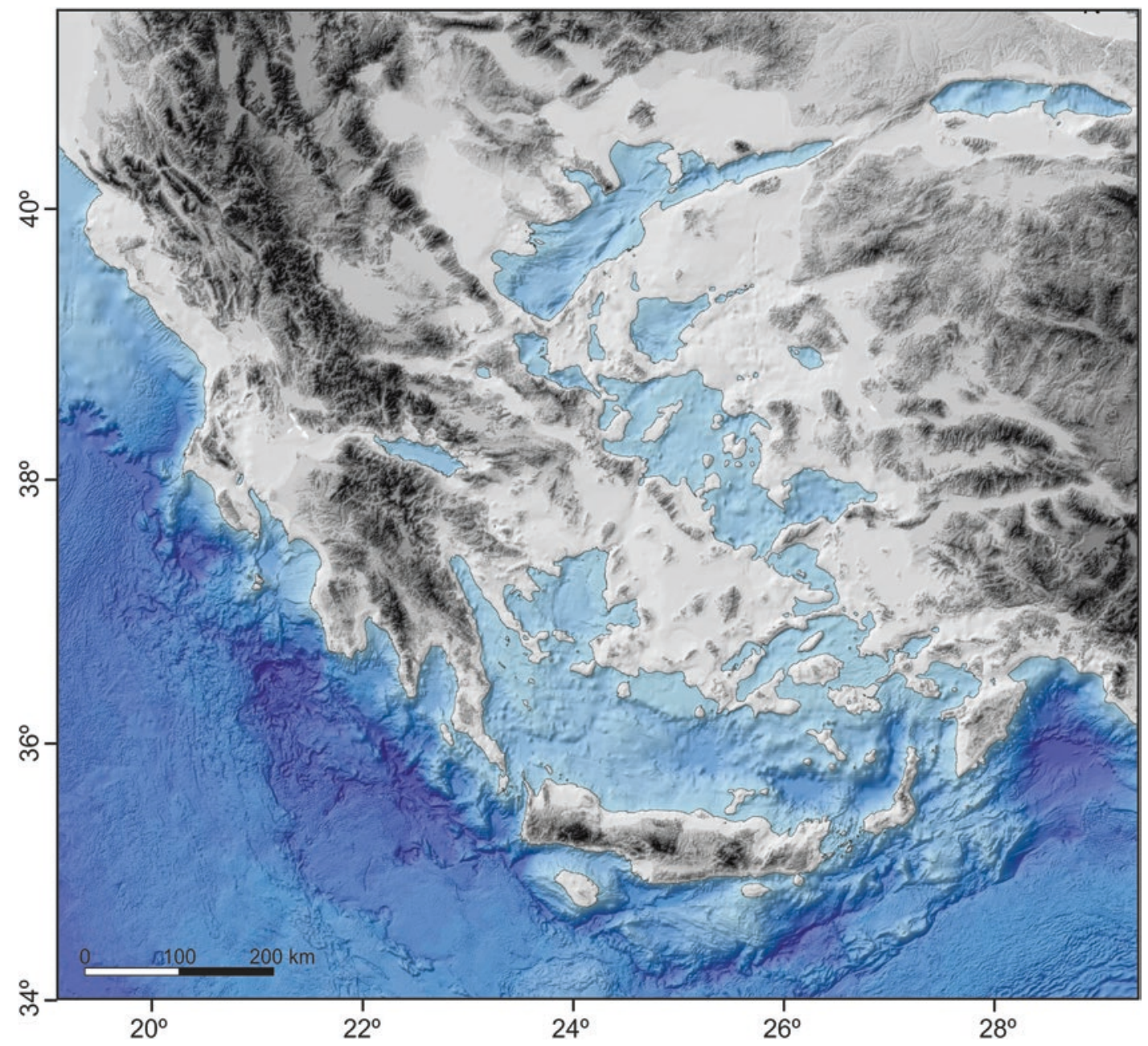

Fig. 19.2 Conceptual palaeogeographic model of the Aegean with areas of land exposed at glacial maxima over the past 500 kyr, modified after Lykousis (2009) and Sakellariou and Galanidou (2016). Land topography is shown in gray (dark gray=high altitudes; light gray=low altitudes). Seafloor topography is shown in blue (dark blue=deep; light blue=shallow). Map created by Dimitris Sakellariou using the latest EMODNET bathymetry (www.emodnet-bathymetry.eu)

dispersal and distribution. At the maximum lowering of sea level of the Last Glacial Maximum (LGM) at $20 \mathrm{ka}$, some sea crossings would have been shorter, and islands would have coalesced to form mega-islands, notably the Cyclades group (Fig. 19.3).

A second consequence of long-term subsidence of the Aegean Basin is that many coastlines have undergone progressive submergence in recent millennia. This means that archaeological remains of settlements occupied after cessation of eustatic sea-level rise, at around 5000-4000 cal BP (Lambeck et al. 2014, Fig. 4a), are now partially or wholly submerged all over coastal Greece, including material from the Final Neolithic to as recent as the Byzantine period. One such example is the cluster of Middle and Late Minoan harbour sites partially submerged in the intertidal zone all along the rim of central and eastern Crete (e.g. Shaw 1990; Theodoulou 2011; Watrouss 2012) or the submerged sandstone quarry and building at Malia (Guest-Papamanoli 


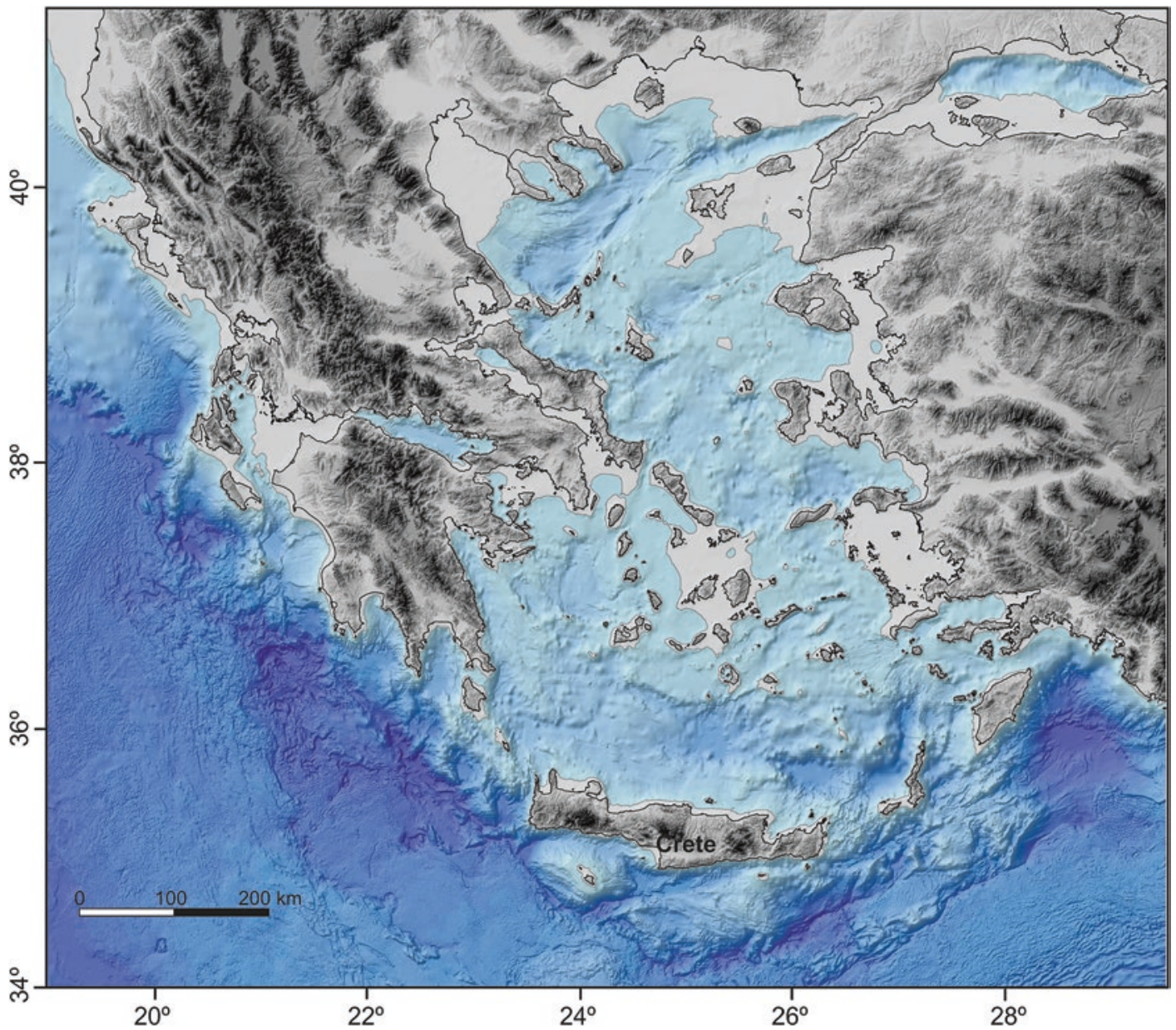

Fig. 19.3 Palaeogeographic reconstruction of the Aegean during the peak of the Last Glacial Maximum, 20 ka BP, based on Lykousis (2009), Kapsimalis et al. (2009), Sakellariou and Galanidou (2016) and references therein. Legend as in Fig. 19.2. Map created by Dimitris Sakellariou using the latest EMODNET bathymetry (www.emodnet-bathymetry.eu)

and Treuil 1979; Guest-Papamanoli 1989). Other later examples are the harbour sites of the Lesbos Pentapolis (Spencer 1995; Theodoulou 2008, 2010, 2017), an inundated Roman villa in the waters of Fourkari, Troizinia near the Ermionis coast (Frost 1977), the submerged antiquities of Samos ranging from harbour installations to a Byzantine hoard (Simossi 1988, 1993; Oekonomides and Drosogianni 1989) and the famous and contested site complex at Kenchreai in the Gulf of Corinth (Scranton et al. 1978). This material is of importance in charting changes of relative sea level and monitoring preservation and recovery patterns despite the potentially destructive impact of waves and currents in the surf zone and in shallow water, but a comprehensive account of the submerged ancient ruins of more recent millennia found in the shallow waters of Greece (e.g. Flemming et al. 1973; Flemming 1978, Table 1; Psychoyos 1988; Baika 2008) lies outside the chronological and thematic scope of this volume.

On the western side of the country, compression and mountain building with a component of strike-slip movement are the main tectonic processes resulting from plate motions, with progressive uplift of the Pindus mountains and submergence of the large basins along the present 
Ionian coastline such as the Amvracian Gulf. Changes of eustatic sea level are the main factor affecting the palaeogeography. At the LGM, the islands of Corfu and Lefkas were attached to the mainland and formed high points in an extensive coastal lowland (Fig. 19.2 and 19.3). However, the Ionian islands of Kephallinia and Zakynthos remained separated from the mainland by deep sea channels, and the Middle Palaeolithic and Upper Palaeolithic artefacts found on these islands must have been deposited there by people capable of making short $(\sim 1-5 \mathrm{~km})$ sea crossings (Ferentinos et al. 2012; Yiannouli 2016, 2017; Papoulia 2017; Zavitsanou et al. 2015).

\subsection{Palaeontological Sites}

Two caves containing Pleistocene animal bones, but no archaeology, are relevant to the theme of this chapter, for they offer evidence of terrestrial deposits preserved below sea level. Glyfada Cave in the Mani Peninsula has a river running through it and an entrance at $0.5 \mathrm{~m}$ apsl (above present sea level) (Fig. 19.4). Of the $10.6 \mathrm{~km}$ thus far explored, $1.8 \mathrm{~km}$ is under water, the water drowning a palaeokarst at an average depth of 20-25 m. Palaeontological remains of Upper Pleistocene terrestrial and marine mammals, such as deer, hyena, panther, lion, hippopotamus, rodents and seals, as well as birds, were collected from depths ranging between 0.5 and $2.5 \mathrm{~m}$ bpsl (below present sea level). They clearly show a cave that was once near the shore and frequented by these animals either as prey or as predators. The largest assemblage of Hippopotamus amphibius in Greece, more than 350 whole bones and 900 fragments, comes from the underwater parts of this cave. A radiocarbon age of 31,650 $\pm 550 \mathrm{BP}$ above the stratigraphic horizon in which most of the bones were collected gives a minimum age (Giannopoulos 2000, p. 402). No synchronous
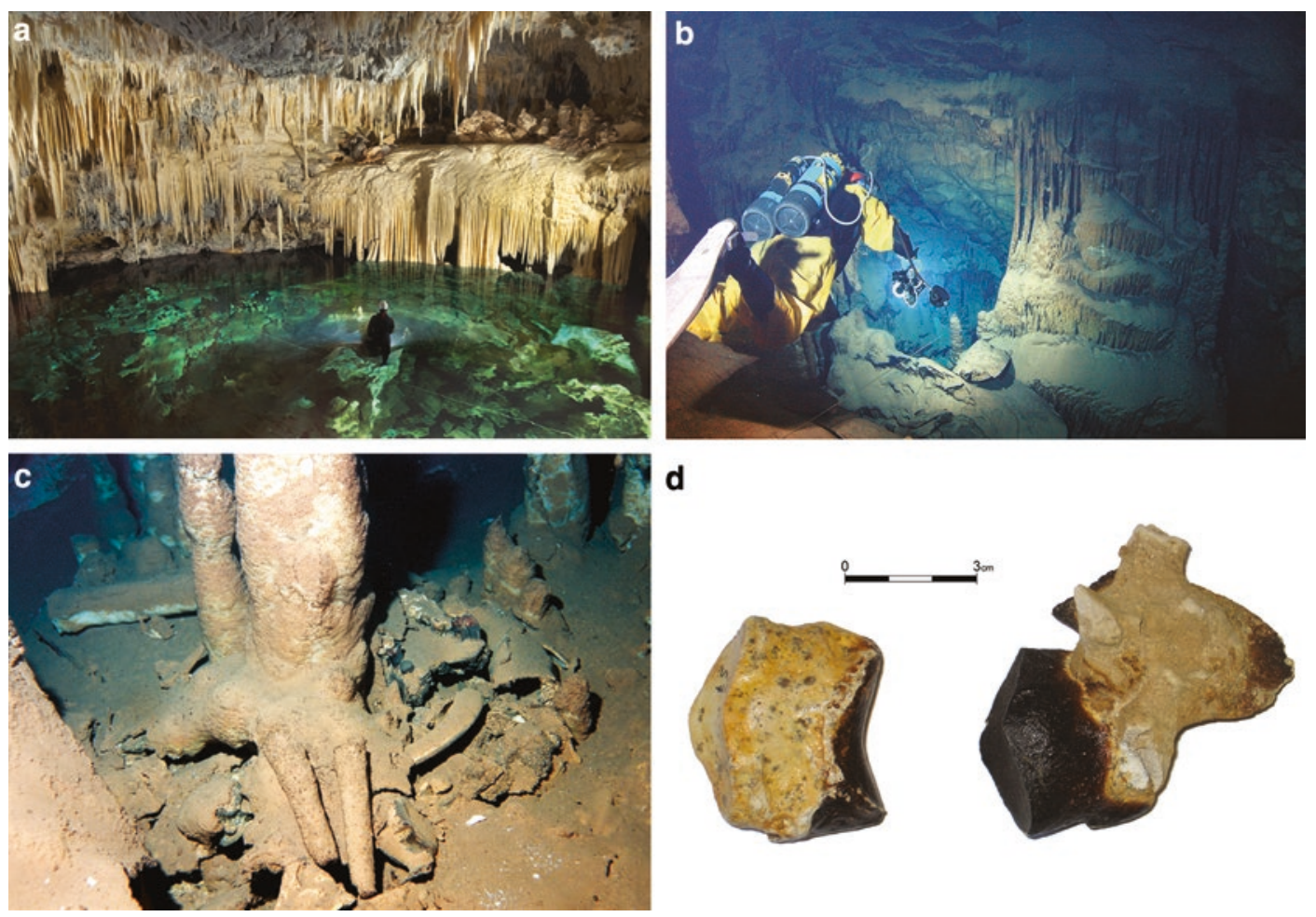

Fig. 19.4 The Glyfada Cave in south Peloponesse: (a) the 'headless panther' chamber of the cave; (b) the 'bat' chamber; (c) underwater view of the palaeokarst at a depth of $-20 \mathrm{~m} \mathrm{bpsl}$; (d) a hippo bone collected from a depth of $-1.5 \mathrm{~m}$ bpsl. Photos courtesy of Vasilis Giannopoulos 
a

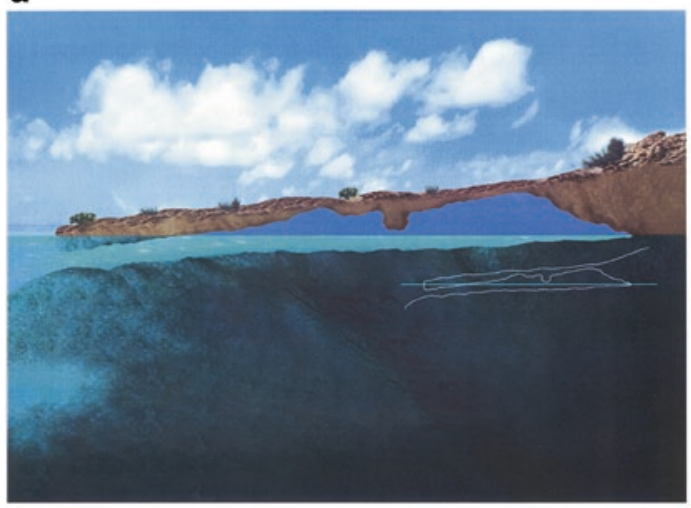

c

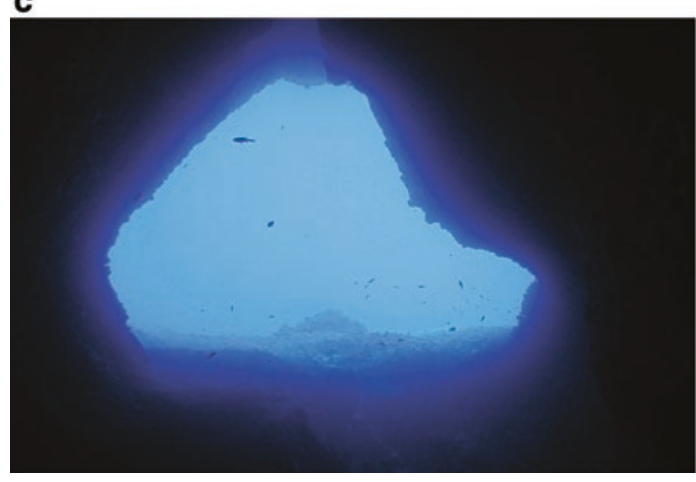

b

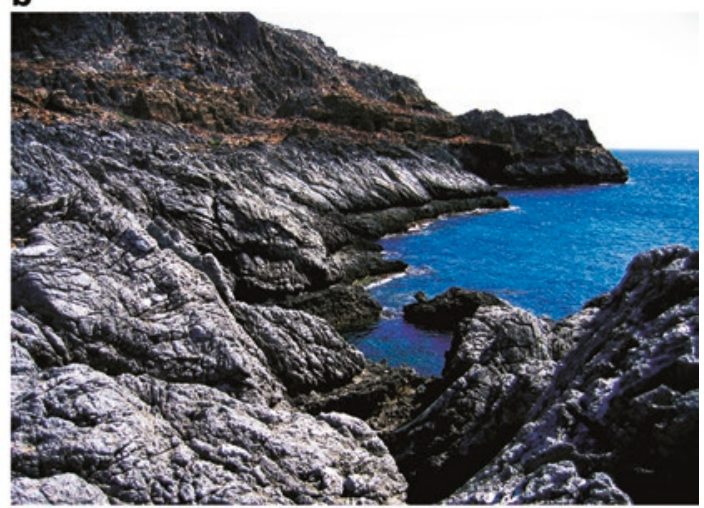

d

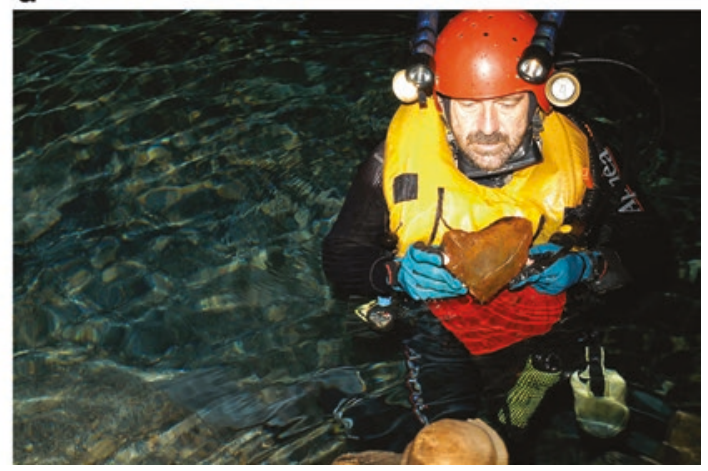

Fig. 19.5 The submerged Vamos Cave in West Crete: (a) reconstruction of the profile (blue denotes air and green denotes water); (b) the landscape around the cave today; (c) the cave entrance: its floor is at $10 \mathrm{~m}$ bpsl whilst the ceiling is at $3.5 \mathrm{~m} \mathrm{bpsl}$; (d) an Elephas chaniensis bone retrieved from a depth of $1.5 \mathrm{~m}$ bpsl. Photos courtesy of Vasilis Giannopoulos

Palaeolithic archaeology has been found here, though the data to hand suggest that before 40,000 years ago, entrance to the cave was possible through a large opening.

On the north coast of western Crete lies Vamos Cave, a large part of which is now underwater. Fossil bones of Pleistocene cervids and elephant, Elephas chaniensis, were found at depths ranging between 1.5 and $4.5 \mathrm{~m}$ bpsl (Fig. 19.5). The latter was a species endemic to Crete that probably went extinct at the end of the Pleistocene. The cave was on dry land during the Last Glacial (Symeonides et al. 2001). The bones were deposited on the cave floor at periods when sea level dropped by at least 10-20 m. At that time, the entrance of the cave was facing the shore.

\subsection{Archaeological Overview}

\subsubsection{Coastal and Underwater Caves}

On the Mani Peninsula in the South Peloponnese, the prevailing hydrogeological conditions of the Taygetos mountain chain favour the occurrence of coastal and submarine groundwater discharges and karst development. This results in the presence of submarine springs at Stoupa and Lakonis, in the Messenian and the Laconian Gulfs, respectively, and many caves in the intertidal and subtidal zones (Sakellariou and Galanidou 2016). Off the shores of western Mani, the seabed features at least 12 submarine 
karstic formations with large concentrations at depths of 25-20 m and 12-8 m bpsl (Bassiakos 1993; Giannopoulos 2000, p. 236). The coastline bordering the Mani Peninsula has numerous caves that were inhabited by Middle Palaeolithic and Upper Palaeolithc hunter-gatherers (Darlas and De Lumley 2002; Darlas and Psathi 2008, 2016). Later, during the Holocene, the coastal caves were used for habitation, burial or ritual activity by Neolithic farmers and herders (Papathanasopoulos 2011).

The contents of three caves situated on the Mani coastline, namely, Kalamakia, Apidima and Lakonis I, indicate a strong Neanderthal presence from the end of the Middle Pleistocene including earlier Neanderthals at Apidima and classic Neanderthals at the other two sites. These three cave sites are the single and only sources of Neanderthal fossils in Greece. The inventory consists of two crania extracted from the Apidima Cave, Apidima 1 and Apidima 2, 14 teeth, cranial and post-cranial fragments from the Kalamakia Cave on the rocky shore of Oitylo bay (not far from Apidima) and a molar from Lakonis I (Harvati et al. 2003, 2010, 2013). Laser ablation U-series dating has returned a minimum age of $160 \mathrm{ka}$ BP for Apidima 2 (Bartsiokas et al. 2017).

\subsubsection{Kalamakia Cave}

Here, recurrent Middle Palaeolithic occupations are dated between 100 and $39 \mathrm{ka} \mathrm{BP}$. The site is $10 \mathrm{~m}$ from the water line and $2.3 \mathrm{~m}$ apsl, at the foot of a 25-m-high cliff (Darlas and De Lumley 1995, 1998, 2002) (Fig. 19.6a). It forms a gallery $20 \mathrm{~m}$ deep, while the mouth is $7 \mathrm{~m}$ wide and $8 \mathrm{~m}$ high (Fig. 19.6b). The Holocene transgression led to sea levels rising to the present level, a little below that of the cave. Winter waves reach the a

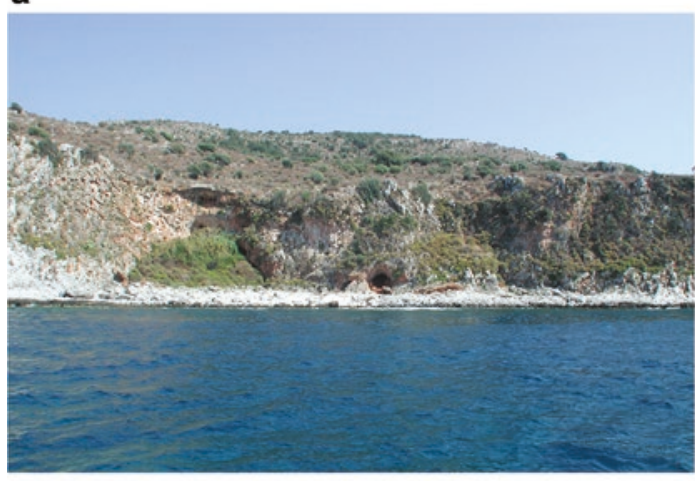

c

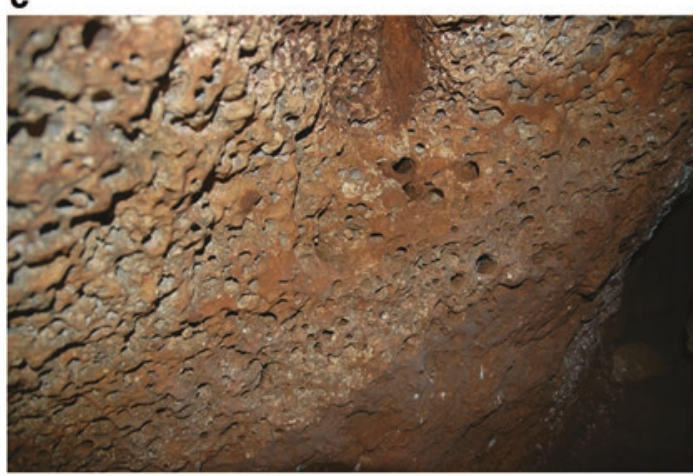

\section{b}

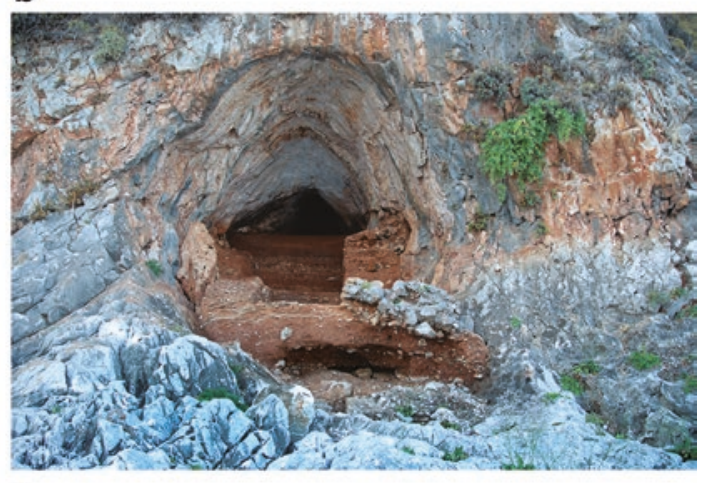

d

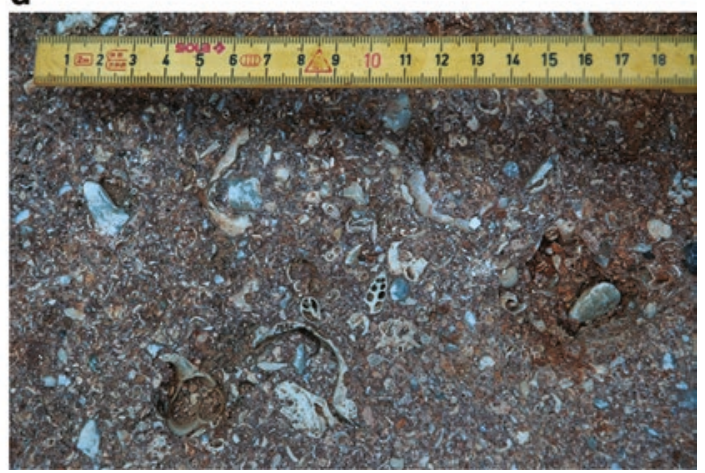

Fig. 19.6 The Kalamakia Cave: (a) general view from offshore; (b) close up of the cave entrance; (c) the cave walls showing dense lithophage bore holes up to the full wall height, an indication that during the Pleistocene the cave was under water for long periods; (d) broken sea shells found in the intact cave fill demonstrate that the inhabitants made use of marine resources. Photos courtesy of Andreas Darlas 
base of the fill, partially eroding it and producing the current condition of the cave. Systematic archaeological excavations conducted on the cave floor show that recurrent Neanderthal occupations took place here. These occupations were not uninterrupted as Pleistocene sea-level changes had dramatic effects on the cave, rendering it alternately a continental and a submarine cave. During the glacial periods, the cave emerged from the sea and was used for Neanderthal habitation, gradually filling with continental sediments and remains of human activities. During interglacial periods the sea rose and flooded it, turning it into an underwater cave and largely stripping it of the previous deposits. Thus, only the deposits of a single cycle, the most recent, were preserved inside the cave each time. Today, therefore, it only contains deposits from the Last Interglacial and the Last Glacial period and almost no evidence of deposits from the preceding phases (Darlas 2012).

The cave walls bear dense lithophage bore holes (Fig. 19.6c) up to their full height, an indication that during the Pleistocene, the cave was underwater for long periods. The $>7 \mathrm{~m}$-thick fill consists of a base of marine deposits dated to the Last Interglacial period, covered by continental deposits dated to the Last Glacial period. The marine deposits consist of two layers. At the base, on the bedrock, is a thin layer of limestone with algae (Unit 0), dating from the MIS 5e transgression, at $\sim 125 \mathrm{ka}$. Above this is a thin layer of beach rock (Unit II) corresponding to MIS $5 \mathrm{c}-\mathrm{a}$ shell from this level has been dated to 109,000+14,000/-13,000 BP (U/Th). Apart from shells and sand (Fig. 19.6b), this layer contains remains of human activity, including artefacts from the terrestrial fill of the preceding phase, MIS 5d, which was washed out by the transgression of phase MIS 5c. In contrast, the sea level rise of MIS 5a was not high enough to reach the cave, and continental deposits from the Last glacial accumulated to a thickness of almost $7 \mathrm{~m}$ (Units III-VI).

\subsubsection{Lakonis}

On the eastern side of the Mani Peninsula $3 \mathrm{~km}$ northeast of Gytheio, lies Lakonis, a cluster of five karstic cavities extending over a distance of $200 \mathrm{~m}$ along the Sellinitsa coast. Excavations conducted at Lakonis I, a cavern whose roof has collapsed, unveiled a sequence spanning the MP and UP; its early stage is coeval with that of Kalamakia (Panagopoulou et al. 2004). The archaeological inventory consists of 50,000 stone artefacts and faunal remains (including deer, wild boar, large bovids, rhinos and hippos). The lithic industries are made of local volcanic rocks, while exogenous flint varieties are also present, bearing witness to possible movements of groups and provisioning of raw materials from a wide catchment area. A series of hearths completes the picture of a recurring use of the site. Part of the larger karstic complex is now submerged, and the waters around it in the Laconian Gulf have been declared a protected heritage zone partly due to the preservation of Middle Palaeolithic terrestrial deposits on the seabed (see http://listedmonuments.culture.gr/fek.php?ID_FEKYA=9716).

\subsubsection{The Mani Submerged Landscape}

Extrapolation from faunal remains in the caves above present sea level suggests that the nowsubmerged landscapes fronting the Mani caves must have once comprised a rich mosaic of lagoons and marshlands, grasslands, parklands and woodlands (Elefanti et al. 2008). These lowland biotopes supported diverse communities of plant and animal life and were important in the survival strategies of the Neanderthals and the later Homo sapiens groups. To judge by the faunal and marine remains recovered from the sites, marine molluscs (Fig. 19.6d) and birds contributed to subsistence as well as hunting of land mammals, and these activities must have taken place on land that is now submerged (Lebreton et al. 2008; Roger and Darlas 2008a, b). Some of the marine shells were modified to use as tools 
(Darlas 2007; Douka and Spinapolice 2012) reinforcing the evidence of a strong relationship to the coast and its resources.

\subsubsection{Offshore Caves and Stone Artefacts}

A small number of submerged caves completes the inventory of inundated karstic contexts, of which those around Corfu are of particular note. Nic Flemming had a leading role in the exploration of the seabed around Corfu more than 30 years ago, and on the west coast, he located a submerged cave at Linodoros Point at a depth of 8-9 m bpsl (Flemming and Kazianis 1987, p. 3 and 6). A cluster of caves now at depths of $40 \mathrm{~m}$ bpsl off the shores of Kyra Panagia, an islet in the Northern Sporades Islands of the Aegean Sea, is also known (Flemming 1983; Efstratiou 2001). The Middle Palaeolithic stone artefacts recovered under water in the same area may originate from archaeological deposits in these caves.

Apart from these cave contexts, loose prehistoric knapped stone artefacts complete the picture. In the Ionian Sea, fishermen from Corfu reportedly trawl up Stone Age artefacts from the seafloor to the north of the island between the islands of Mathraki, Othonoi and Errikousa (Sordinas pers. comm. 2003). In 1987, research on the shore of western Corfu and offshore by Nic Flemming resulted directly from previous work by Augustus Sordinas (1983). The main acoustic surveys have not been published, although the tapes were submitted to the Ephorate of Underwater Antiquities (Flemming pers. comm. 2013). This work brought to light lithic artefacts, cores, flakes, debitage and the occasional tool of unconfirmed Stone Age date on land, scattered among the rocks on the shore. Lithics were found on the seabed at distances ranging from 200 to $700 \mathrm{~m}$, at Agios Georgios and the Diaplo islet, to $2 \mathrm{~km}$ away from the nearest shore at Karavi (Flemming and Kazianis 1987, p. 4). A diagnostic Mousterian tool produced by the Levallois technique was recovered about $200 \mathrm{~m}$ offshore off the village of Aghios Georgios in SW Corfu and reported by Flemming (pers. comm. 2013)

\subsubsection{Neolithic and Bronze Age Sites}

\subsubsection{Agios Petros}

On the other side of Greece, the small islet of Agios Petros, in the Northern Sporades (Fig. 19.7), has a Neolithic village, part of which lies submerged to a depth of $10 \mathrm{~m}$ bpsl (Flemming 1983, 1985). Excavations of the terrestrial sector conducted by Theocharis in 1969-1971 and Efstratiou in 1981 brought to light houses on the outskirts of the village on a promontory with a natural harbour. The site has returned a single radiocarbon date (BM-2020R) of 5740-5530 cal $\mathrm{BC}$ (1 $\sigma$ range). Occupation began towards the end of the Early Neolithic (EN) and beginning of the Middle Neolithic (MN) and lasted for a millennium. A wide range of ceramic vessels, figurines, fishing equipment made of bone, and knapped, polished and ground stone tools were recovered (Efstratiou 1985). The typical early painted and monochrome ceramics recovered suggest affinities with the contemporaneous EN cultural traditions of Thessaly and the Cyclades, with those of Anatolia across the Aegean and with the Balkan Peninsula to the north. A unique tradition, by Greek standards, of painted (red-onwhite) ceramics and figurines is recorded on site. The latter shows very characteristic resemblances with Anatolian figurines (Haçilar VI) and one of Balkan type (rod-head figurine). It is estimated that the small village was inhabited by no more than a few dozen people. They lived in rectangular stone houses/structures, of which only a few survive in a bad state of preservation due to weather erosion. Two child burials in bedrock cuttings were also found.

Dimitris Theocharis opened the way to underwater work on the islet, but his work has remained unpublished. In 1981 Nic Flemming conducted new underwater investigation to map the submarine topography and history of the coastline and to examine the presence of archaeological remains (Flemming 1983, 1985). He excavated several 1-m-square quadrats on the seabed (Fig. 19.7a, b) and sampled the sediments for particle-size analysis. Animal bones, lithics and ceramic finds were retrieved from the sea floor. 

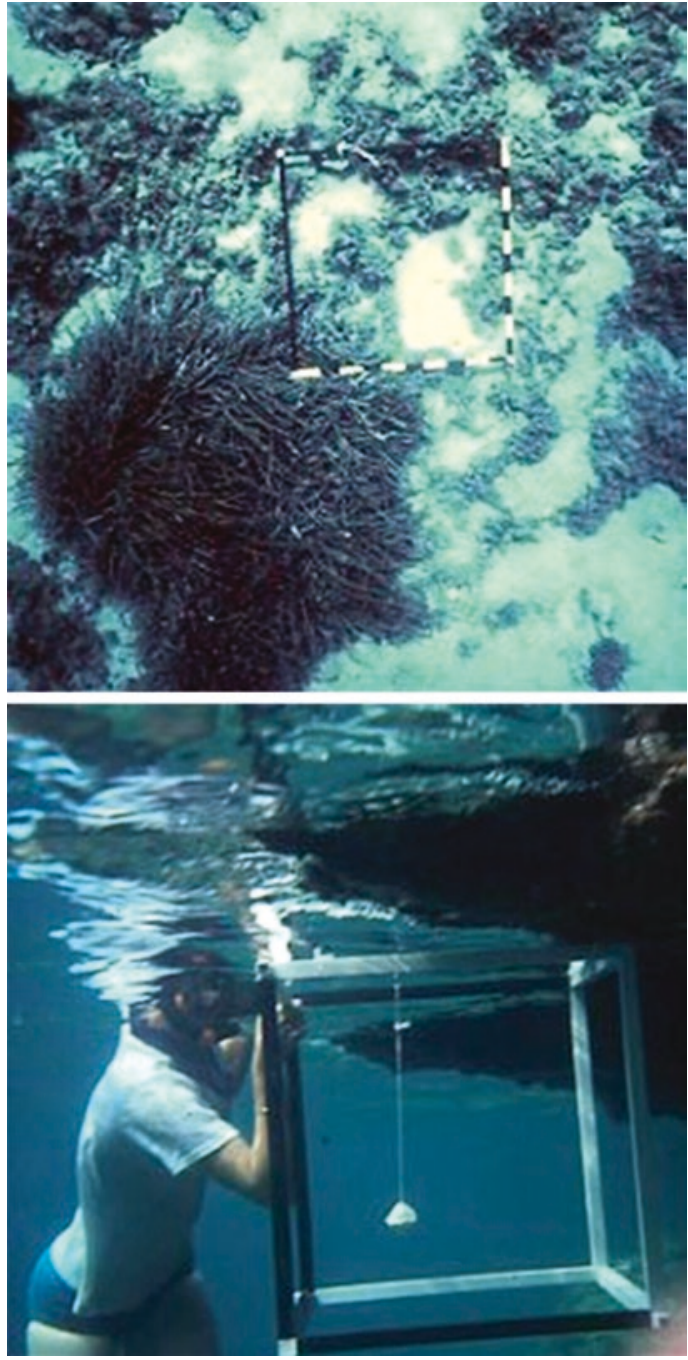

Fig. 19.7 Underwater investigations and mapping of the seabed offshore of Agios Petros, Kyra Panagia, Northeast Aegean, conducted by Nic Flemming in 1973. Upper: 1-m square grid on the seabed; lower: 1-m-square frame for use in excavation being lowered onto the sea. Photos courtesy of Nic Flemming

The study of the rich faunal assemblages found above and below sea level inform on a diet based on domesticated animals (94.2-97.4\% of the assemblage) such as sheep, goat and pig. Birds including the bone of a cormorant and marine fish are also recorded. The different lines of underwater archaeological evidence indicate that marine submergence had a scattering rather than a destructive effect upon the material (Flemming 1985, p. 140). Since EN times, sea level at Agios
Petros has risen in the order of $10 \mathrm{~m}$. Two successive episodes of sea-level rise are identifiable, both occurring in the life-span of the Neolithic village, and they were at times rapid enough for deposits to be drowned without prolonged exposure to the sorting effects of wave action (Efstratiou 1985, p. 164). Underwater reconnaissance discovered two submarine springs, and these were probably the main water supply for this small Neolithic community.

\subsubsection{Pavlopetri}

Pavlopetri lies in the shallow waters of the Vatika Bay in the southeast of the Malea Peninsula in the Peloponnese and is perhaps the most impressive and best-known submerged site in the Aegean Basin by virtue of its size, content and preservation quality (Fig. 19.8). A century after its original discovery by geologist Phokion Negris (1904) and more than 40 years after its rediscovery by Nic Flemming (1968a, b) and early exploration by Harding et al. (1969), new offshore work has begun under the scientific direction of Jon Henderson to shed light on this site and its palaeogeographic setting (Henderson et al. 2011) in collaboration with the Ephorate of Underwater Antiquities (EUA) and the Hellenic Centre for Marine Research (HCMR).

The site was inhabited from at least the Early Bronze Age (EBA) through to the end of the Late Bronze Age. It exists on land, on the islet and on the seafloor at a depth of 1-4 m bpsl. The submerged part of the settlement, extending from about $20 \mathrm{~m}$ off the Pounda shore to $300 \mathrm{~m}$ south, consists of Bronze Age buildings, rooms, courtyards, streets, cist graves and rock-cut tombs found in situ (Fig. 19.9 and 19.10). Henderson et al. $(2011,2013)$ estimate that it covered an area of approximately 8 ha and had a likely maximum settlement population ranging between 500 and 2000 people (Henderson et al. 2013, p. 247). Sea level has risen by an estimated $4-5 \mathrm{~m}$ during the last 5000 years.

Almost $40 \%$ of the ceramic component recovered in the 2009 season dates to the EBA. Coupled with the discovery of a monumental trapezoidal building comparable with other EBA structures, all this suggests that, contra earlier interpreta- 


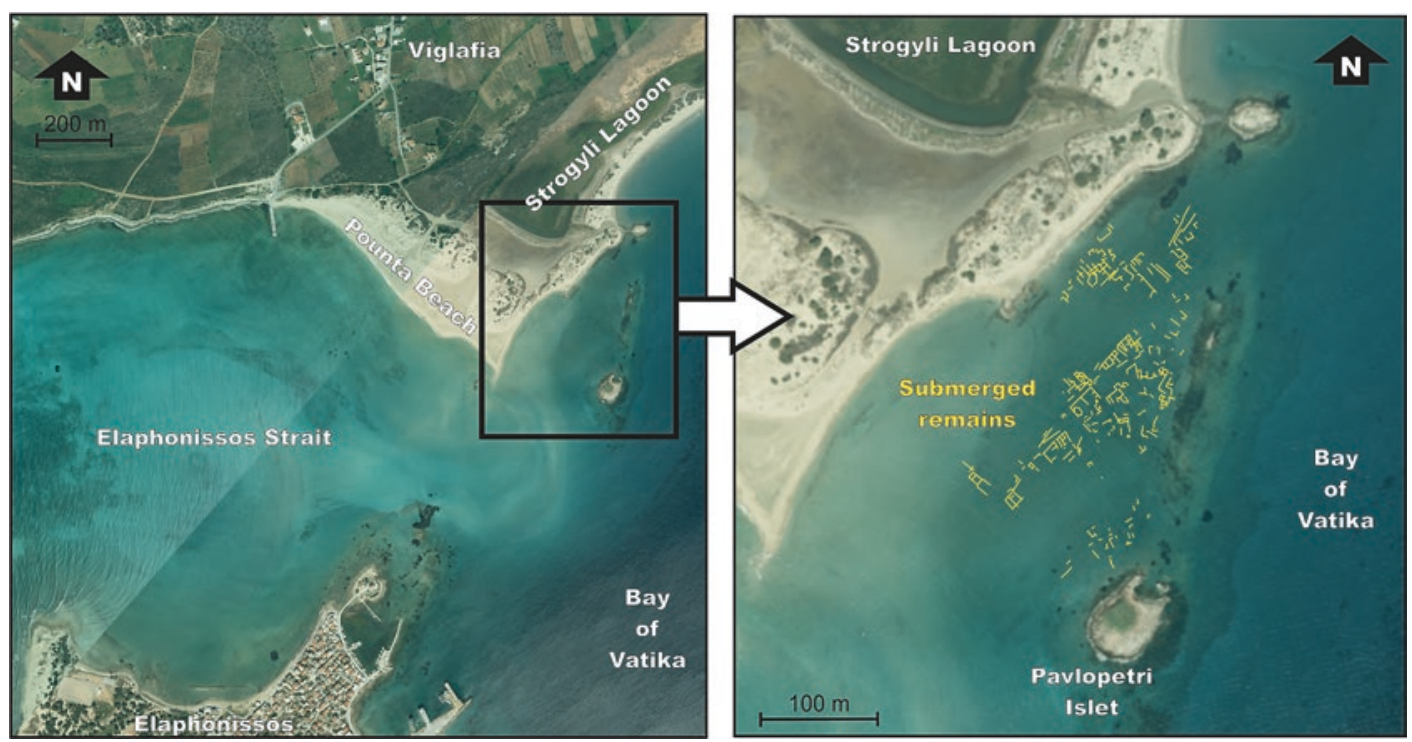

Fig. 19.8 Aerial view of Pavlopetri submerged remains at Pounta Beach, Viglafia, on the north-western edge of the Bay of Vatika, Peloponnese. Modified after Henderson et al. 2013

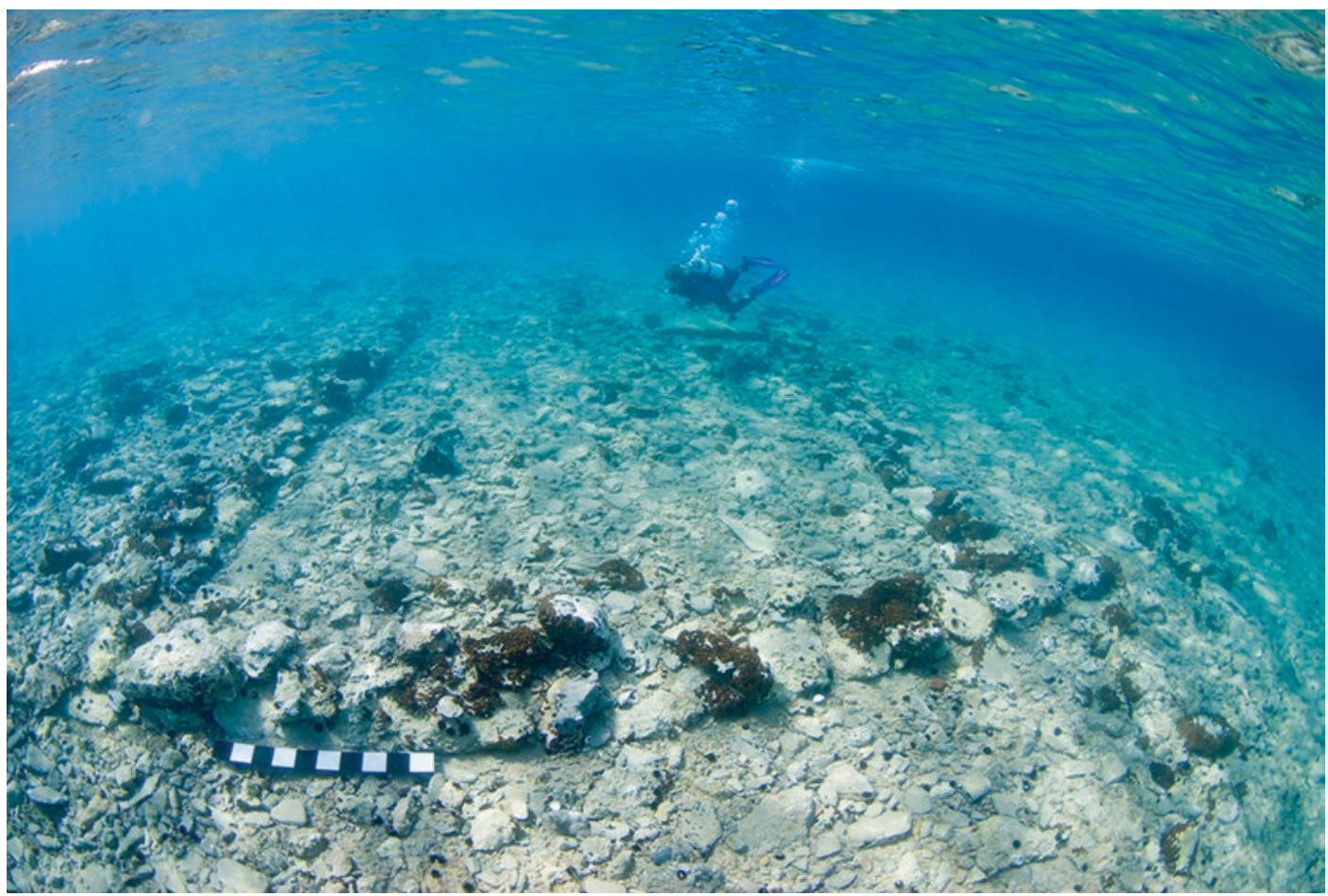

Fig. 19.9 Submerged architectural remains at Pavlopetri, with remains of a stone wall showing the outline of a rectangular building. Photo courtesy of Jon Henderson and the Pavlopetri Project 


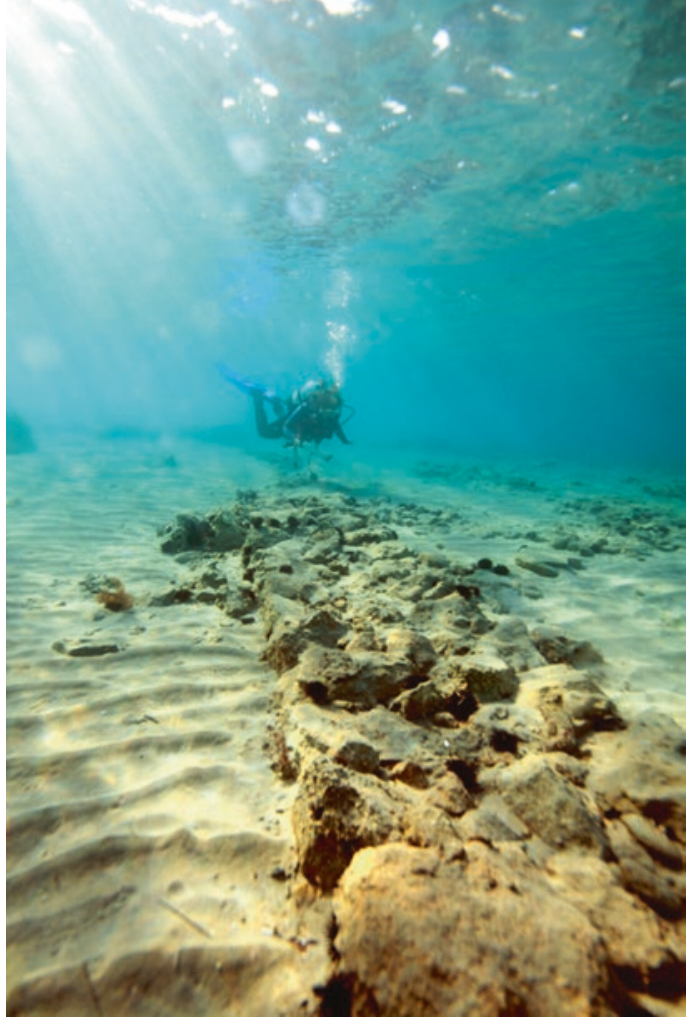

Fig. 19.10 Close-up of the remains of a wall foundation at Pavlopetri. Photo courtesy of Jon Henderson and the Pavlopetri Project

tions, settlement at Pavlopetri may indeed be a typical case of the EBA preference for promontories with immediate access to the sea and its resources of marine foods and opportunities for seaborne communication. Pottery finds at Pavlopetri are suggestive of links with contemporaneous Cycladic, Cretan and north-eastern Aegean cultural traditions (Henderson et al. 2011, 2013).

\subsubsection{Platiyali}

The submerged EBA settlement at Platiyali is situated in the innermost part of a closed $1 \mathrm{~km}$ wide and $2 \mathrm{~km}$-long bay south of Astakos in Aetoloakarnania. The bay lies between the Capes of Carlo Glossa and Steni Gonia and its entrance is protected by the Echinades islets in the Inner Ionian Sea. The underwater investigation in the area took place in 1986 because of planned con- struction of a ship-breaking yard. To judge from the slight seabed slope, the area where the settlement was established must have been a low coastal plain before it became inundated. Freshwater springs are present today both under water and on the shoreline. Building walls are discernible across a 400-m zone along the shoreline to a distance of $130 \mathrm{~m}$ from the shore, and to a depth of at least $5 \mathrm{~m}$ bpsl. The settlement area lying on the seabed is estimated to cover at least 5 ha and was submerged at $4.5 \mathrm{ka}$ BP. A remarkable finding is the burial of an infant in a vessel. The settlement layout, the architectural forms, including examples of an Early Helladic megaron at $23 \times 11 \mathrm{~m}$, the ceramic shapes and techniques, the stone-knapping technology and use of obsidian and the presence of child-burials in jars, all lead to the conclusion that Platiyali conforms to the general character of the Early Helladic II culture in the Aegean (Dellaporta and Spondylis 1987, 1988; Dellaporta et al. 1988, 1990).

The coastal location of Platiyali and the rather difficult access to it from the land meant that the inhabitants naturally looked to the sea to provide the main route of communication with other cultural centres. It is therefore quite likely that the site was an important port-of-call for the maritime trade in obsidian, acting as a gateway community into north-west Greece. The submergence of the settlement some 4500 years ago was the reason for its preservation to this day.

\subsubsection{Salanti}

Salanti Argolidas is a third EBA settlement, situated in the middle of the Didymon cove, just north of the Franchthi Cave. It extends $400 \mathrm{~m}$ on a north-west-south-east axis and is approximately $30 \mathrm{~m}$ wide in parallel with the beach and at a depth of $4 \mathrm{~m}$ bpsl. The Ephorate of Underwater Antiquities conducted a seabed survey and estimated the settlement area at 8.9 ha. The slight slope of the seabed indicates that the settlement was originally located in a low valley and at some distance from the sea. Visible on the seabed are foundation walls made of rough stones and of two types: a double layer of 50-60 cm thickness with intermediate fill and a single layer of $30 \mathrm{~cm}$ 
thickness. A semi-circular building $4 \mathrm{~m}$ in diameter belongs to the latter type. Both types are often found in EBA settlements in the Peloponnese and Central Greece. The inventory of finds includes beak-spouted jugs, domestic coarse ware, open vessels with textured impressions on the upper part and grinding stones and piercers made on volcanic material from the Saronic Gulf. The typology of ceramic finds suggests an EH II date (Blackman 2001, p. 30).

The geographic location and topography of Pavlopetri, Platiyiali and Salanti corresponds to those of many Aegean sites, where occupation begins in the Early Bronze Age and often runs through to the end of this period. The inventory of villages partly submerged or eroded by the sea is long: Manika on Euboea (Sampson and Maroukian 1989), Agia Irini on Kea (Caskey 1962, 1964, 1966, 1971, 1972; Mourtzas 2010), Nea Makri in Attica (Theocharis 1954, 1956; Gkopha 2000; Kourtir and Chalakies on Lesbos (Chatzi 1986; Spencer 1995; Argyri and Theodoulou 2012) and Sissi Spiliada and Psathi on Crete (Hood 1965; Mytilinaiou 1997; Simossi 2003; Theodoulou 2015). At Agia Irini, the occupation began during the Final Neolithic. Built in coastal settings, preferably located on peninsulas or promontories by natural harbours, these sites were excellent departure and arrival points for sea journeys to the wider world. They were usually involved with transport of goods and commerce through maritime routes and are evidence of a widespread coastally oriented way of life. At Agios Kosmas in Attica, an EBA coastal cemetery is submerged in shallow water in the Saronic Gulf (Mylonas 1952, 1959).

\subsubsection{The Glyfada-Mesi Hoard}

In recent years, one of the most dramatic underwater discoveries is the EBA hoard of 110 bronze axes discovered on the seabed of Glyfada-Mesi in Rhodope, Thrace (Simossi 2009), the largest hoard of this period found in Greece or the neighbouring Balkans. It was found at a depth of $3.5 \mathrm{~m}$ bpsl and at a distance of $450 \mathrm{~m}$ from the nearest shore. A type of double axe with two percussion surfaces is the dominant artefact type, while lathhammers and single-bladed axes are also present in smaller numbers. The submerged site extends to an area of approximately $10 \mathrm{~m}^{2}$ (Morgan et al. 2009, p. 67). Embedded in the sea floor below the tools are the bases of two EH vessels and slag with impressions of basket-work is also present. Simossi (2009, p. 100) suggests that the hoard was deliberately concealed on dry land, a recognized practice of the period in sites of the mainland, north and central Aegean, before the sea level rose.

\subsection{Mapping the Prehistoric Record of the Greek Shelf}

A new direction of research lies in the development of collaborations between archaeologists and oceanographers to map the submerged landscape. Three such projects are currently underway, both using known Stone Age sites on land as a starting point for offshore exploration.

The first project 'Exploring the Submerged Caves and Prehistoric Landscapes of the Inner Ionian Sea Archipelago' is focussed on the coastal and inundated landscape of the semienclosed marine area between the western coast of Central Greece (Akarnania), and the islands of Lefkas, Kephallinia and Ithaca. The point of departure is the record of Middle Palaeolithic sites on Lefkas and the islands and islets of the Inner Ionian Sea (Galanidou 2015, 2018; Galanidou et al. 2016b, 2018; Papoulia 2017, 2018). The area was frequented by Neanderthal groups and the palaeogeography of settlement, and the nature of the interconnections between the present-day islands would have been especially sensitive to sea-level change. A seismic reflection survey conducted in the northern part of the archipelago has given new information on the palaeogeographic evolution of the area during the Late Quaternary low sea-level periods of MIS 2, 6 and 8 (Zavitsanou et al. 2015; Zavitsanou 2016). With a single exception, that of Atokos, the islands of the Inner Ionian Sea Archipelago were connected to the mainland during low sealevel stands and easily accessible on foot. The archaeology of Atokos has significant implications for the early history of sea crossings in a 
semi-enclosed and protected sea where the destination was visible and close at hand (Galanidou 2018; Papoulia 2018). Further out to sea, to the south-west, the islands of Kephallinia and Ithaca have remained separated from the mainland throughout the last $300 \mathrm{kyr}$.

The second project has a longer history that began in the late 1970s and early 1980s with the search in the Bay of Kiladha in the Western Argolic Gulf for a submerged Neolithic settlement related to the Franchthi Cave occupation. On this occasion, marine geophysical surveying and coring in the bay was conducted (Van Andel et al. 1980; Van Andel 1987; Gifford 1983, 1990). Gifford reported that Neolithic pottery was found in situ in sediments at a water depth of $4.5 \mathrm{~m}$, and $5.5 \mathrm{~m}$ below the sediment surface. Two cores were taken through the seabed midway between the Franchthi headland and Koronis Island, offering conclusive evidence that a palaeo-river flowed through this strait, with occupation on the banks of the river.

The search for submerged traces of prehistoric human activity near the cave was resumed in 2012 by the Bay of Kiladha project and was intensified in 2014 with the Terra Submersa expedition, a collaboration between the University of Geneva, the Hellenic Centre for Marine Research, the Greek Ephorate of Underwater Antiquities, PlanetSolar, the Laténium (Switzerland) and the Swiss School of Archaeology in Greece (Beck et al. 2017; see https://www.unige.ch/terrasubmersa/en). Offshore and nearshore surveys were conducted on board two vessels: the Swiss solarpowered PlanetSolar and HCMR's research vessel Alkyon. Detailed swath bathymetry, side-scan sonar imaging and sub-bottom profiling in the wider Gulf and in Koilada Bay, along with offshore drilling in the Koilada Bay offshore of Franchthi Cave in collaboration with the University of Bern, revealed detailed information on palaeoshorelines of the Neolithic period and earlier (MIS 2 and 6). They identified the exposed Neolithic surface and demonstrated the presence of pottery sherds, one dating to the Early to Middle Neolithic period (Sakellariou et al. 2015; Surdez et al. 2018; Beck et al. 2017).
The third project was instigated by archaeological work conducted on Lesbos Island, in the northeast Aegean Sea, which began in 2012 with the investigation of Rodafnidia, Lisvori, the first large-scale Acheulean site in south-east Europe and western Anatolia, dated by relative and p-IRSL methods to the Middle Pleistocene (Galanidou et al. 2013, 2016a). A systematic marine survey in the Kalloni Gulf and off the southern coast of the island has been coordinated by the Department of History and Archaeology of the University of Crete and implemented by the Hellenic Centre for Marine Research in collaboration with the Department of Marine Sciences of the Aegean University with the aim of reconstructing the palaeoenvironment and the palaeoshorelines during the low sea-level periods of the last $500 \mathrm{kyr}$ in the broader area. Processing and interpretation of the seismic profiling data are in progress and are expected to shed light on the palaeogeography of the area and on the terrestrial connection between Lesbos and the west Anatolia.

\subsection{Management of the Underwater Cultural Heritage}

The protection of antiquities is enshrined in the Constitution of Greece (Article 24), and the government organization legally responsible for the protection of archaeological sites and monuments is the General Directorate of Antiquities and Cultural Heritage under the Ministry of Culture and Sports. Responsibility for underwater archaeology lies with the Ephorate of Underwater Antiquities (EUA), founded in 1976, https://www.culture.gr/en/ministry/SitePages/ viewyphresia.aspx?iID=1369. Under the Archaeological Law of 2002 https://www.forin. gr/laws/law/2795/gia-thn-prostastia-twn-arxaiothtwn-kai-en-genei-ths-politistikhs-klhronomias, specific regulations were introduced for the first time to cover the entire spectrum of underwater antiquities with regard to their protection and management as a whole, in keeping 
with the United Nation's Convention on the Law of the Sea and in the spirit of the UNESCO Convention on the Protection of the Underwater Cultural Heritage, although Greece is not yet a formal signatory to the latter Convention (Dellaporta 2004, 2013, 2014; see also Peeters et al., Chap. 24, this volume; Dromgoole, Chap. 26 , this volume). The mission of the EUA is the exploration and protection of the underwater heritage of the Greek seas, rivers and lakes, the discovery, study, conservation and public promotion and understanding of the submerged ancient heritage, including shipwrecks, settlements and harbours, declaration of protected underwater areas and supervision of oceanographic research and works conducted beneath the sea (for a history of EUA and its activities, see Kritzas 1978; Dellaporta 2002; Simossi 2009; Theodoulou 2011).

The Hellenic Centre for Marine Research (HCMR) of the Ministry of Education is a largescale marine research institute that has contributed significantly to the exploration of the submerged cultural heritage, leading to the discovery and study of numerous deep- and shallowwater archaeological sites (https://www.hcmr.gr/ en). It owns and operates three oceanographic vessels, a two-person submersible and four remotely operated vehicles (ROVs), which support the activities of all research sectors and are being used for the exploration of the marine environment and the seafloor. The HCMR has established the new field of Marine Geo-Archaeology with its main objective the multidisciplinary research of submerged antiquities and landscapes (Sakellariou 2010; Sakellariou et al. 2010, 2011). It has introduced the use of state-of-the-art marine techniques in deep and shallow water and archaeological surveys promoting collaboration between marine geoscientists, engineers and archaeologists.

Both institutions have been working to improve knowledge, raise public interest and contribute to the conservation and protection of the underwater cultural heritage in line with the UNESCO Convention, EU declarations and the national law.
Acknowledgements We would like to thank Augustus Sordinas and Nic Flemming for sharing with us their precious knowledge on the archaeology of the seabed of Greece, a knowledge that largely remains unpublished. Hauke Jöns has provided much-appreciated support in assembling the geographic evidence for the Greek submerged material included in the SPLASHCOS Viewer. Moritz Mennenga has been efficient in retrieving information from the data base and producing various versions of the map of the submerged archaeology of Greece at very short notice. Nikos Efstratiou, Evgenia Yiannouli, Andreas Darlas and Thanasis Yiannopoulos shared with us information on their coastal and underwater fieldwork, photos and bibliography. Panos Zervoudakis contributed valuable bibliographic support and editorial skills especially during the finishing stages of this work. They are all warmly acknowledged.

\section{References}

Ammerman AJ (2014) Setting our sights on the distant horizon. In: Ammerman AJ, Davis T (eds) Proceedings of the Wenner Gren Foundation workshop on Island archaeology and the origins of seafaring in the eastern Mediterranean, Reggio Calabria, October 19-21, 2012. J Eurasian Prehistory 10 (1-2):203-236

Argyri S, Theodoulou T (2012) Archaeological survey in the Kalloni Gulf Lesbos (2005). Enalia XI Annual, IENAE, Athens, pp 100-109 (in Greek)

Baika K (2008) Archaeological indicators of relative sealevel changes in the Attico-Cycladic massif: preliminary results. Bull Geol Soc Greece 42(2):33-48

Bartsiokas A, Arsuaga JL, Aubert M, Grün R (2017) U-series dating and classification of the Apidima 2 hominin from Mani Peninsula, Southern Greece. J Hum Evol 109:22-29

Bassiakos IE (1993) Dating of fossils from caves and speleothems: evidence from Electron Spin Resonance (E.S.R.) technique, the study of underground karst morphology and the relevant radiometric and geological conditions in speleoenvironments of Dyros, Mani. Unpublished $\mathrm{PhD}$ thesis submitted to the University of Athens (in Greek)

Beck J, Sakellariou D, Koutsoumba D (2017) Submerged Neolithic landscapes off Franchthi Cave: the measurements from the Terra Submersa expedition and their implications. In Sarris A, Kalogiropoulou E, Kalayci $\mathrm{T}$, Karimali L (eds) Communities, landscapes, and interaction in Neolithic Greece. Proceedings of the International conference Rethymno 29-30 May 2015, Archaeological series 20, pp 261-268

Blackman D (2001) Archaeology in Greece 2000-2001. Archaeol Rep 47:1-144

Caskey LJ (1962) Excavations in Keos 1966-1970. Hesperia 31:263-283

Caskey LJ (1964) Excavations in Keos 1966-1970. Hesperia 33:314-335 
Caskey LJ (1966) Excavations in Keos 1966-1970. Hesperia 35:363-376

Caskey LJ (1971) Investigations in Keos I. Hesperia 40:358-396

Caskey LJ (1972) Investigations in Keos II. Hesperia 40:357-401

Chatzi D (1986) Skamnioud-Kourtir. Archaeologikon Deltion 41:484

Darlas A (2007) Le Moustérien de Grèce à la lumière des récentes recherches. L'Anthropologie 111:346-366

Darlas A (2012) Geomorphological evolution and occupation of the caves of the western coast of Mani during the late Pleistocene and Holocene. In: Zacharias N, Georgakopoulou M, Polykreti K, Fakorellis G, Vakoulis T (eds) Proceedings of the 5th symposium of the Greek Archaeometry Society 2008. Papazisi, Athens, pp 237-253 (in Greek)

Darlas A, De Lumley H (1995) Fouilles franco-helléniques de la grotte de Kalamakia (Aréopolis, Péloponnèse). Bull Corresp Hell 119(2):793-798

Darlas A, De Lumley H (1998) Fouilles franco-helléniques de la grotte de Kalamakia (Aréopolis; Péloponnèse). Bull Corresp Hell 122(2):655-661

Darlas A, De Lumley H (2002) Fouilles franco-helléniques de la grotte de Kalamakia (Aréopolis, Péloponnèse). Bull Corresp Hell 126(2):685-689

Darlas A, Psathi E (2008) Le Paléolithique supérieur dans la péninsule du Mani (Péloponnèse, Grèce). In: Darlas A, Mihailovic D (eds) The Palaeolithic of the Balkans, British archaeological reports international series 1819. Archaeopress, Oxford, pp 51-59

Darlas A, Psathi E (2016) The middle and upper Palaeolithic in the West of Mani Peninsula (Southern Greece). In: Harvati K, Roksandic M (eds) Paleoanthropology of the Balkans and Anatolia: human evolution and its context, Vertebrate paleobiology and paleoanthropology series. Springer, Dordrecht, pp 95-118

Dellaporta C (2002) Underwater cultural heritage in Greece. Problems of protection and promotion. Strumenti per la protezione del patrimonio culturale marino aspetti archeologici. Atti del convegno (8-10 marzo 2001), pp 125-128

Dellaporta KP (2004) Tutela legale e gestione del patrimonio archeologico subacqueo in Grecia. Mediterraneum 4:65-73

Dellaporta KP (2013) Das Archäologische Kulturerbe unter Wasser in Griechenland - Erforschung, Gefährdung und Schutzmaßnahmen. In: Reinfeld M (ed) Archäologie im Mittelmeer. Auf der Suche nach versunkenen Schiffswracks und vergessenen Häfen,

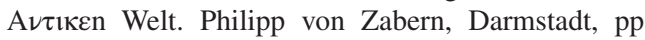
73-80

Dellaporta KP (2014) The international and national legislation for the protection of underwater antiquities. In: Choúlia-Kapelonī $\mathrm{S}$ (ed) 3rd international conference of experts on the return of cultural property, Athens ancient Olympia, October 23-26, 2013: proceedings. Archaeological Receipts Fund, Athens, pp 87-92

Dellaporta A, Spondylis I (1987) Un habitat Helladique Ancien II à Platiyali Astakou. In: Tzalas HE (ed)
Tropis II. 2nd International symposium on ship construction, Delphi 1987, Proceedings. Hellenic Institute for the Preservation of Nautical Tradition, Athens, pp 27-29

Dellaporta A, Spondylis I (1988) Platiyiali Astakos: a submerged Early Helladic settlement. Proceedings of the first archaeological and historical conference of Aetoloakarnania, Agrinio, 21-23 October 1988. Agrinio, pp 39-46 (in Greek)

Dellaporta A, Spondilis E, Baxevanakis Y (1988) Early Helladic settlement at Platiyiali Astakos (preliminary observations). Anthropologica Analecta 49:7-19 (in Greek)

Dellaporta A, Spondilis E, Baxevanakis Y (1990) Platiyali-Astakos: a submerged Early Helladic site in Akarnania. Enalia 1:44-46

Douka K, Spinapolice EE (2012) Neanderthal shell tool production: evidence from Middle Palaeolithic Italy and Greece. J World Prehistory 12:45-79

Efstratiou N (1985) A Neolithic site in the Northern Sporades. Aegean relationships during the Neolithic of the 5th millennium BC. BAR International series 155. British Archaeological Reports, Oxford

Efstratiou N (2001) The Neolithic settlement of Agios Petros in Kyra-Panagia, Halonnesos and the island habitation patterns in the Aegean - a reconsideration. In: Sampson A (ed) Archaeology in the Northern Sporades. Municipality of Alonessos, Alonessos, pp 231-250 (in Greek)

Efstratiou N (2005) Tracing the story of the first farmers in Greece-a long and winding road. In: Lichter C (ed) How did farming reach Europe? Anatolian-European relations from the second half of the 7 th through the first half of the 6th millennium cal BC: proceedings of the international workshop, Istanbul, 20-22 May 2004 (BYZAS 2). Deutsches Archäologisches Institut Abteilung, Istanbul, pp 143-153

Elefanti P, Panagopoulou E, Karkanas P (2008) The transition from the Middle to the Upper Palaeolithic in the southern Balkans: The evidence from the Lakonis I Cave, Greece. Eurasian Prehistory 5:85-95

Evans JD (1994) The early millennia: Continuity and change in a farming settlement. In: Hood S, Evely D, Evely RDG, Hughes-Brock H, Momigliano N (eds) Knossos: a labyrinth of history. Papers presented in honour of Sinclair Hood. British School at Athens, London, pp 1-20

Ferentinos G, Gkioni M, Geraga M, Papatheodorou G (2012) Early seafaring activity in the southern Ionian Islands, Mediterranean Sea. J Archaeol Sci 39:21672176. https://doi.org/10.1016/j.jas.2012.01.032

Flemming NC (1968a) Holocene earth movements and Eustatic sea level change in the Peloponnese. Nature 217:1031-1032

Flemming NC (1968b) Mediterranean sea level changes. Sci J 4:51-55

Flemming NC (1978) Holocene Eustatic changes and coastal tectonics in the northeast Mediterranean: implications for models of crustal consumption. Philoso Trans R Soc London 289(1362):405-458 
Flemming NC (1983) Preliminary geomorphological survey of an early Neolithic submerged site in the Sporadhes, N. Aegean. In: Masters PM, Flemming NC (eds) Quaternary coastlines and marine archaeology. Academic Press, London, pp 233-268

Flemming NC (1985) Preliminary geomorphological survey of the Neolithic site of Agios Petros. In: Efstratiou $\mathrm{N}$ (ed) A Neolithic site in the Northern Sporades. Aegean relationships during the Neolithic of the 5th millennium BC, BAR International series 155. British Archaeological Reports, Oxford, pp 137-141

Flemming NC, Kazianis D (1987) Preliminary report on the Otranto Straits project. Unpublished report submitted to the Department of Antiquities, Underwater Section, Greece

Flemming NC, Czartoryska NMG, Hunter PM (1973) Archaeological evidence for eustatic and tectonic components of relative sea level change in the South Aegean. In: Blackman DJ (ed) Marine archaeology, Colston Papers 23. Butterworth Press, London, pp 1-66

Frost FJ (1977) Phourkari. A villa complex in the Argolid (Greece). Int J Naut Archaeol 6(3):233-238

Galanidou N (2011) Mesolithic cave use in Greece and the mosaic of human communities. J Mediterr Archaeol 24(2):219-242

Galanidou N (2015) Seascape survey on the Inner Ionian Sea Archipelago. In: Carver M, Gaydarska B, Monton $\mathrm{S}$ (eds) Field archaeology from around the world. Ideas and approaches. Springer, Cham, pp 101-106

Galanidou N (2018) Parting the waters: Palaeolithic archaeology in the central Ionian Sea. J Greek Archaeol 3:1-22

Galanidou N, Cole J, Iliopoulos G, McNabb J (2013) East meets west: The Middle Pleistocene site of Rodafnidia on Lesvos, Greece. Antiquity Project Gallery 87(336). http://www.antiquity.ac.uk/projgall/galanidou336/

Galanidou N, Athanassas C, Cole J, Iliopoulos G, Katerinopoulos A, Magganas A, McNabb J (2016a) The Acheulian Site at Rodafnidia, Lisvori, on Lesbos, Greece: 2010-2012. In: Harvati K, Roksandic M (eds) Paleoanthropology of the Balkans and Anatolia: human evolution and its context, Vertebrate paleobiology and paleoanthropology series. Springer, Dordrecht, pp 119-138

Galanidou N, Iliopoulos G, Papoulia C (2016b) The Palaeolithic settlement of Lefkas. Archaeological evidence in a palaeogeographic context. J Greek Archaeol 1:1-31

Galanidou N, Vikatou O, Gatsi-Stavropoulou M, Vasilakis A, Iliopoulos G, Staikou V, Veikou M, Forsén J, Morgan C, Vroom J, Papoulia C, Zervoudakis P, Prassas K (2018) The archaeological survey in the Inner Ionian Sea Archipelago. In: Vikatou O, Staikou V, Saranti F (eds) Archaeological work in Aetoloakarnania and Lefkas from prehistoric to Roman times. Proceedings of the 2nd International archaeological and historical conference, December 6-8 2013, Messolonghi. Messolonghi pp 445-473 (in Greek)

Giannopoulos B (2000) Contribution to the study of modern and old environments of the most important Greek caves. Unpublished PhD thesis, University of Athens (in Greek)

Gifford J (1983) Core sampling of a Holocene marine sedimentary sequence and underlying Neolithic cultural material off Franchthi Cave, Greece. In: Masters PM, Flemming NC (eds) Quaternary coastlines and marine archaeology. Academic Press, London, pp 269-282

Gifford JA (1990) Analysis of submarine sediments off Franchthi Cave. In: Wilkinson TJ, Duhon ST (eds) Franchthi Paralia: the sediments, stratigraphy, and offshore investigations. Indiana University Press, Bloomington/Indianapolis, pp 85-116

Gkopha MP (2000) Neolithic Attica (Vol. 13). Archeological Society at Athens (in Greek)

Guest-Papamanoli A (1989) Les carrières de grès dunaire à Malia. Bull Corresp Hell 113(1):113-122

Guest-Papamanoli A, Treuil R (1979) Bâtiment immergé. Bull Corresp Hell 103:668-669

Harding A, Cadogan G, Howell R (1969) Pavlopetri: an underwater Bronze Age town in Laconia. Annu Br Sch Athens 64:113-142

Harvati K, Panagopoulou E, Karkanas P (2003) First Neanderthal remains from Greece: the evidence from Lakonis. J Hum Evol 45:465-473

Harvati K, Stringer C, Karkanas P (2010) Multivariate analysis and classification of the Apidima 2 cranium from Mani, Southern Greece. J Hum Evol 60(2):246-250

Harvati K, Darlas A, Bailey SE, Rein TR, El Zaatari S, Fiorenza L, Kullmer O, Psathi E (2013) New Neanderthal remains from Mani peninsula, Southern Greece: The Kalamakia Middle Paleolithic cave site. J Hum Evol 64(6):1-14

Henderson J, Gallou C, Flemming NC, Spondylis E (2011) The submerged prehistoric town at Pavlopetri in southern Greece. In: Benjamin J, Bonsall CL, Pickard C, Fischer A (eds) Submerged prehistory. Oxbow, Oxford, pp 207-218

Henderson J, Pizarro O, Johnson-Roberson M, Mahon I (2013) Mapping submerged archaeological sites using stereo-vision photogrammetry. Int $\mathrm{J}$ Naut Archaeol 42(2):243-256

Hood MSF (1965) Minoan sites in the far west of Crete. The Annual of the British School at Athens 60:99-113

Kapsimalis V, Pavlopoulos K, Panagiotopoulos I, Drakopoulou P, Vandarakis D, Sakellariou D, Anagnostou C (2009) Geoarchaeological challenges in the Cyclades continental shelf (Aegean Sea). Zeitschrift für Geomorphologie, Supplementary Issue 53(1):169-190

Kopaka K, Matzanas C (2009) Palaeolithic industries from the island of Gavdos, near neighbour to Crete in Greece. Antiquity Project Gallery 83(321). http:// antiquity.ac.uk/projgall/kopaka321/

Koufos GD, Kostopoulos DS (2016) The Plio-Pleistocene large mammal record of Greece: implications for early human dispersals into Europe. In: Harvati K, Roksandic M (eds) Paleoanthropology of the Balkans and Anatolia: human evolution and its 
context, Vertebrate paleobiology and paleoanthropology series. Springer, Dordrecht, pp 269-280

Kritzas C (1978) Underwater archaeology in Greece. In: Rackl HW (ed) Diving into the past. Gutenberg, Athens, pp 414-429 (in Greek)

Lambeck K (1995) Late Pleistocene and Holocene sealevel change in Greece and south-western Turkey: a separation of eustatic, isostatic, and tectonic contributions. Geophys J Int 122:1022-1044. https://doi. org/10.1111/j.1365-246X.1995.tb06853.x

Lambeck K (1996) Sea-level change and shoreline evolution in Aegean Greece since Upper Palaeolithic time. Antiquity 70:588-611

Lambeck K, Rouby H, Purcell A, Sun Y, Sambridge M (2014) Sea level and global ice volumes from the Last Glacial Maximum to the Holocene. Proc Natl Acad Sci 111(43):15296-15303

Lebreton V, Psathi E, Darlas A (2008) Environnement vegetal des Neanderthaleniens de la grotte de Kalamakia (Areopolis, Grèce). In: Darlas A, Mihailovic D (eds) The Palaeolithic of the Balkans, British archaeological reports international series 1819. Archaeopress, Oxford, pp 61-68

Lykousis V (2009) Sea-level changes and shelf break prograding sequences during the last 400ka in the Aegean margins: subsidence rates and palaeogeographic implications. Cont Shelf Res 29(16):2037-2044

Lyras GA, van der Geer AA (2007) The late Pliocene vertebrate fauna of Vatera (Lesvos Island, Greece). Cranium 24(2):11-24

Morgan C, Pitt RK, Whitelaw T (2009) Archaeology in Greece 2008-2009. Archaeol Rep 55:1-101

Mourtzas ND (2010) Sea level changes along the coasts of Kea island and paleogeographical coastal reconstruction of archaeological sites. Bull Geol Soci Greece 43(1):453-463

Mouslopoulou V, Begg J, Nicol A, Oncken O, Prior C (2015) Formation of late quaternary paleoshorelines in Crete, Eastern Mediterranean. Earth Planet Sci Lett 431:294-307

Mylonas GE (1952) Aghios Kosmas excavation 1951. Archaeologiki Efimeris 91:117-134 (in Greek)

Mylonas GE (1959) Aghios Kosmas: an early bronze settlement and cemetery in Attica. Princeton University Press, Princeton

Mytilinaiou DK (1997) Proanaktoriki keramiki apo ti thesi Psathi Kydonias. Kritiki Estia 6:194-236

Negris P (1904) Vestiges antiques submergés. Mitteilungen des Deutschen Archäologischen Instituts, Athenische Abteilung 29:340-363

Oekonomides M, Drosogianni P (1989) A hoard of gold Byzantine coins from Samos. Rev Numismatique 31:145-182

Panagopoulou E, Karkanas P, Tsartsidou G, Kotjabopoulou E, Harvati K, Ntinou M (2004) Late Pleistocene archaeological and fossil human evidence from Lakonis cave, southern Greece. J Field Archaeol 29(3-4):323-349

Papathanasopoulos GA (2011) Neolithic Diro, Alepotrypa Cave, vol I. Melissa and Diro Centre of Neolithic Studies, Athens (in Greek)
Papoulia C (2017) Seaward dispersals to the NE Mediterranean islands in the Pleistocene. The lithic evidence in retrospect. Quat Int 431:64-87

Papoulia C (2018) Pleistocene sea-crossings and submerged terrestrial routes. A view from the Inner Ionian Archipelago. PhD Dissertation, University of Crete

Perissoratis C, Conispoliatis N (2003) The impacts of sealevel changes during latest Pleistocene and Holocene times on the morphology of the Ionian and Aegean seas (SE Alpine Europe). Mar Geol 196:145-156

Perlès C (1979) Des navigateurs méditerranéens il y a10,000 ans. La Recherche 96:82-83

Pirazzoli PA (1988) Sea-level changes and crustal movements in the Hellenic Arc (Greece). The contribution of archaeological and historical data. In: Raban A (ed) Archaeology of coastal changes, British archaeological reports international series 404. Archaeopress, Oxford, pp 157-184

Pirazzoli PA, Thommeret J, Thommeret Y, Laborel J, Montaggioni L (1982) Crustal block movements from Holocene shorelines: Crete and Antikythira (Greece). Tectonophysics 86:27-43

Pirazzoli PA, Laborel J, Stiros SC (1996) Earthquake clustering in the Eastern Mediterranean during historical times. J Geophys Res Solid Earth 101(B3):6083-6097

Psychoyos O (1988) Déplacements de la ligne de rivage et sites archéologiques dans les régions côtières de la Mer Égée, au Néolithique et à l'Âge du Bronze, vol. 62. P. Åströms förlag, Jonsered

Renfrew C, Aspinall A (1990) Aegean obsidian and Franchthi Cave. In: Perlès C (ed) Les industries lithiques taillées de Franchthi (Argolide, Grèce), tome 2: Les industries lithiques du Mésolithique et du Néolithique initial, Excavations at Franchthi Cave, fasc, 5. Indiana University Press, Bloomington/ Indianapolis, pp 257-70

Roger T, Darlas A (2008a) Upper Pleistocene bird remains from Kalamakia Cave (Greece). In: Darlas A, Mihailovic D (eds) The Palaeolithic of the Balkans, British archaeological reports international series 1819. Archaeopress, Oxford, pp 69-76

Roger T, Darlas A (2008b) Microvertèbres, paléoenvironnment et paléoclimat de la grotte de Kalamakia (Péloponnèse, Grèce). In: Darlas A, Mihailovic D (eds) The Palaeolithic of the Balkans, British archaeological reports international series 1819. Archaeopress, Oxford, pp 77-84

Sakellariou D (2010) Submerged cultural remains in longterm uplifting regions: examples from the Hellenic Arc. In: Proceedings, INQUA 501 - IGCP 521 Sixth plenary meeting and field trip, Hydrobiological Station of Rhodes, 27 Sept-6 Oct 2010, Rhodes

Sakellariou D, Galanidou N (2016) Pleistocene submerged landscapes and Palaeolithic archaeology in the tectonically active Aegean region. In: Harff J, Bailey G, Lüth F (eds) Geology and archaeology: submerged landscapes of the continental shelf. Geological Society London Special Publications 411, London, pp 145-178. https:// doi.org/10.1144/SP411.9

Sakellariou D, Galanidou N (2017) Aegean Pleistocene landscapes above and below sea-level: 
Palaeogeographic Reconstruction and hominin dispersals. In: Bailey GN, Harff J, Sakellariou D (eds) Under the sea: archaeology and palaeolandscapes of the continental shelf. Springer, Cham, pp 335-359

Sakellariou D, Tsampouraki-Kraounaki K (2018) PlioQuaternary extension and strike-slip tectonics in the Aegean. In: Duarte J (ed) Transform plate boundaries and fracture zones. Elsevier, New York

Sakellariou D, Lykousis V, Rousakis G (2010) Reconstructing prehistoric landscapes in tectonically active regions: the Corinth and North Evia prehistoric lakes during LGM. XIX Congress of the CarpathianBalkan Geological Association/Special Session S30, Thessaloniki, Greece, 23-26 September 2010

Sakellariou D, Bailey G, Flemming NC (2011) "Project Deukalion" discovering Europe's submerged prehistoric landscapes on the seabed. In: DG MARE, Lunchtime conference - submerged prehistoric landscapes, Brussels, 28 June 2010. http://www.splashcos. org/research/dpg

Sakellariou D, Lykousis V, Geraga M, Rousakis G, Soukisian T (2017) Late Pleistocene environmental factors of the Aegean Region (Aegean Sea including the Hellenic Arc) and the identification of potential areas for seabed prehistoric sites and landscapes. In: Flemming NC, Harff J, Moura D, Burgess A, Bailey GN (eds) Submerged landscapes of the European continental shelf: quaternary paleoenvironments. Wiley, Chichester, pp 405-429

Sakellariou D, Beck J, Rousakis G, Georgiou P, Panagiotopoulos I, Morfis I, Tsampouraki-Kraounaki K, Zavitsanou A (2015) Submerged prehistoric landscapes off Franchthi Cave, East Argolic Gulf: Preliminary results. In: 11th Panhellenic symposium on oceanography and fisheries, proceedings. Mytilene, pp 993-996

Sampson AA, Maroukian H (1989) The Coastal topography and archaeology of Manika, an Early Helladic town in West Central Euboea Greece. In: Parish R (ed) Archaeometry. Proceedings of the 25th International symposium Athens 19-23 May 1986. Elsevier, New York, pp 461-467

Sampson AA, Kaczanowska M, Kozłowski JK (2010) The prehistory of the island of Kythnos (Cyclades, Greece) and the Mesolithic settlement at Maroulas. Polish Academy of Arts and Sciences, Kraków

Scranton R, Shaw JW, Ibrahim L (1978) Topography and architecture (Kenchreai I). Brill, Leiden

Shaw JW (1990) Bronze Age Aegean harboursides. In: Hardy DA, Doumas CG, Sakellarakis JA, Warren PM (eds) Thera and the Aegean World III, vol. I, Archaeology. Proceedings of the third international congress, Santorini, Greece, 3-9 September 1989. The Thera Foundation, London, pp 420-436

Shaw B, Ambraseys NN, England PC, Floyd MA, Gorman GJ, Higham TFG, Jackson JA, Nocquet JM, Pain CC, Piggott MD (2008) Eastern Mediterranean tectonics and tsunami hazard inferred from the AD 365 earthquake. Nat Geosci 1:268-276
Simossi A (1988) The ancient port of Samos. Archaeologica Analekta ex Athinon XXI: 111-125 (in Greek)

Simossi A (1993) Le port du guerre de Thasos. In: Lazarov M, Angelova C (eds) Thracia Pontica 6. La Thrace et les sociétés maritimes anciennes. Sozopol, pp 271-286

Simossi A (2003) A Coastal Minoan settlement at Speliada, Seision, Crete. Enalia Annual VII: 57-65 (in Greek)

Simossi A (2009) Ephorate of Underwater Antiquities. 30 years of research activity. Archaiologia 115:95-105 (in Greek)

Sordinas A (1983) Quaternary shorelines in the region of Corfu and adjacent islets, western Greece. In: Masters PM, Flemming NC (eds) Quaternary coastlines and marine archaeology. Academic Press, London/New York, pp 335-344

Spencer N (1995) A gazeteer of archaeological sites in Lesbos, British archaeological reports international series 623. Archaeopress, Oxford

Stiros S (2001) The AD 365 Crete earthquake and possible seismic clustering during the fourth to sixth centuries AD in the Eastern Mediterranean: a review of historical and archaeological data. J Struct Geol 23:545-562

Strasser TF, Panagopoulou E, Runnels CN, Murray PM, Thompson N, Karkanas P, McCoy FW, Wegmann KW (2010) Stone age seafaring in the Mediterranean: evidence from the Plakias region for Lower Palaeolithic and Mesolithic habitation of Crete. Hesperia 79:145190. https://doi.org/10.2972/hesp.79.2.145

Surdez M, Beck J, Sakellariou D, Vogel H, Birchler EP, Koutsoumba D, Anselmetti FS (2018) Flooding a landscape: impact of Holocene transgression on coastal sedimentology and underwater archaeology in Kiladha Bay (Greece). Swiss J Geosci. Published online 03 May 2018. https://doi.org/10.1007/s00015-018-0309-4

Symeonides NK, Theodorou GE, Giannopoulos VI (2001) New data on Elephas chaniensis (Vamos cave, Chania, Crete). In: Cavarretta G, Gioia P, Mussi M, Palombo MR (eds) The world of elephants. Proceedings of the First International Congress. Consiglio Nazionale delle Ricerche, Rome, pp 510-513

Theocharis DR (1954) Excavation of a Neolithic settlement in Nea Makri. PAE 1954:114-122 (in Greek)

Theocharis DR (1956) Nea Makri, Eine grosse Neolithische Siedlung in der nahe von Marathon. Mitteilungen des Deutschen Archäologischen Instituts, Athenische Abteilung 71:1-29

Theodoulou T (2008) The harbour network of ancient Lesbos. First step of an underwater approach. In: Tzalas H (ed) Tropis X, Hydra, vol 28. Hellenic Institute for the Preservation of Nautical Tradition, Athens, pp 93-102

Theodoulou T (2010) Underwater research in the ancient ports of Lesbos. Archaiologia 116:93-102 (in Greek)

Theodoulou T (2011) Underwater archaeological research in Greece - a brief outline. Ariadni 17:13-84 (in Greek) 
Theodoulou $\mathrm{T}$ (2015) Brief review of underwater and coastal archaeological research in Crete until 2014. Kritika Chronika 35:31-52

Theodoulou T (2017) Recording the harbour network of ancient Lesbos (2007 mission). In: Triantafyllides P (ed), Archaeological work in the Aegean Islands, International conference, Rhodes 27 November - 1 December 2013, vol. B, Mytilene, pp 123-130

Van Andel TH (1987) The adjacent sea. In: Van Andel TH, Sutton SB (eds) Landscape and people of the Franchthi Region, Fascicle 2, Excavations at Franchthi Cave, Greece Indiana University Press, Bloomington/ Indianapolis, pp 31-54

Van Andel TH, Jacobsen TW, Jolly JB, Lianos N (1980) Late Quaternary history of the coastal zone near Franchthi Cave, Southern Argolid, Greece. J Field Archaeol 7:389-402

Van Hinsbergen DJJ, Meleunkamp JE (2006) Neogene supradetachment basin development on Crete (Greece) during exhumation of the South Aegean core complex. Basin Res 18:103-124

Watrous LV (2012) The harbor complex of the Minoan town at Gournia. Am J Archaeol 116(3):521-541
Yiannouli E (2016) A.Sho.Re. 2011-2015, SE Kephallenia in the Ionian Sea: Investigating the geoarchaeology of the coastal zone. In: Photos-Jones E, Bassiakos Y, Filippaki E, Hein A, Karatasios I, Kilikoglou V, Kouloumpi E (eds) Proceedings of the 6th Symposium of the Hellenic Society for Archaeometry, Athens 16-18 May 2013, The Acropolis Museum. British Archaeological Reports IS 2780, Oxford, pp 179-185

Yiannouli E (2017) The work of the University of the Peloponnese in the island of Kefalonia: The research program of the coastal zone (Archaeological Shoreline Research).In: 10th International Panionian conference, 30 April-4 May 2014, Kerkyraika Chronika, Kerkyra, pp 327-340 (in Greek)

Zavitsanou A (2016) Paleogeographical Reconstruction of the Northern Inner Ionian Sea Archipelago during Late Quaternary Low Sea Level Periods. M.Sc. Dissertation, University of Athens (in Greek)

Zavitsanou A, Sakellariou D, Rousakis G, Georgiou P, Galanidou N (2015) Paleogeographic reconstruction of the Sea during Late Pleistocene low sea level stands: preliminary results. In: Proceedings of the 11th Panhellenic symposium on oceanography and fisheries, 13-17 May 2015, Mytilene, Greece. Mytilene, pp 997-1000

Open Access This chapter is licensed under the terms of the Creative Commons Attribution 4.0 International License (http://creativecommons.org/licenses/by/4.0/), which permits use, sharing, adaptation, distribution and reproduction in any medium or format, as long as you give appropriate credit to the original author(s) and the source, provide a link to the Creative Commons licence and indicate if changes were made.

The images or other third party material in this chapter are included in the chapter's Creative Commons licence, unless indicated otherwise in a credit line to the material. If material is not included in the chapter's Creative Commons licence and your intended use is not permitted by statutory regulation or exceeds the permitted use, you will need to obtain permission directly from the copyright holder. 